\title{
LEOPOLD LENARD - SŁOWEŃSKI POLONOFIL Z POCZĄTKU XX WIEKU ${ }^{1}$
}

\section{Antoni Cetnarowicz}

(1) http://orcid.org/0000-0001-5309-7609

Uniwersytet Jagielloński w Krakowie (Polska)

\section{ABSTRACT \\ LEOPOLD LENARD: A SLOVENE POLONOPHILE FROM THE EARLY $20^{\text {TH }}$ CENTURY}

The article provides some facts about the life, writings and cultural activity of a Slovene Polonophile, Leopold Lenard, at the time of his highest activity, i.e. in the early $20^{\text {th }}$ century. In the context of his extensive amount of work and intense activism, which included political, socio-cultural and religious issues, one subject stands out as his lifelong interest: the "Slavic idea", the idea of cooperation among Slavs, in particular maintaining the closest possible relations with Poles.

Keywords: Slovenes, Polish-Slovene relations, idea of Slavic mutuality, Pan-Slavism.

Słowa kluczowe: Słoweńcy, stosunki polsko-słoweńskie, idea wzajemności słowiańskiej, panslawizm.

Dzieje Słoweńców mało były dotąd znane współczesnemu Polakowi. Fakt ten może dziwić, tym bardziej że przecież przez blisko 150 lat znaczna część narodu polskiego zamieszkiwała Galicję znajdującą się, podobnie jak Słoweńcy, w obrębie tego samego państwa pod berłem Habsburgów. Dopiero wydarzenia związane z rozpadem Jugosławii na początku lat 90. XX wieku i powstanie niepodległej Słowenii zwróciły baczniejszą uwagę polskiej opinii na istnienie i losy naszych południowych pobratymców. Wciąż jednak liczne są przykłady, zwłaszcza w środowisku dziennikarskim, świadczące o myleniu Słoweńców ze Słowakami lub zaliczające ich do narodów bałkańskich. A co dopiero kiedy przyjdzie nam wskazać na jakieś przykłady

1 Artykuł powstał w ramach projektu OPUS 13, finansowanego przez Narodowe Centrum Nauki w Krakowie, pt. „Pomiędzy dwoma zjazdami w Pradze. Związki między Słowianami w Europie Środkowej i Południowo-Wschodniej w latach 1848-1908" (2017/25/B/HS3/00240).

Adres do korespondencji: antoni.cetnarowicz@uj.edu.pl 
politycznych czy kulturalnych związków polsko-słoweńskich. Dlatego przybliżenie osoby i działalności słoweńskiego polonofila z początków XX wieku powinno zasługiwać na naszą uwagę.

Leopold Lenard urodził się w dniu 2 listopada 1876 roku w majątku Scharfenberg w miejscowości Svibno powiat Krško w Krainie, na obszarze dzisiejszej Słowenii². Pięć klas gimnazjum ukończył w państwowym gimnazjum w Lublanie, a szóstą i siódmą w prywatnym gimnazjum we włoskiej Weronie. Ostatnią, ósmą, klasę ukończył i zdał maturę (z wynikiem celującym) w gimnazjum państwowym w Brixen w Tyrolu. W roku 1902 podjął studia teologiczne w Innsbrucku. Materiały do doktoratu gromadził także w czasie kwerend w Monachium. Doktoryzował się z teologii w roku 1903 w Innsbrucku. W latach 1903-1904 studiował filozofię na Uniwersytecie we Lwowie, wysłany tam przez arcybiskupa Antona Jegliča. Studia te kontynuował na Uniwersytecie Wiedeńskim, skąd przybył do Krakowa i zapisał się na semestr zimowy 1906/1907 na Wydział Filozoficzny Uniwersytetu Jagiellońskiego, z opóźnieniem, ale za zgodą dziekana w dniu 16 listopada 1906 roku $^{3}$ Z księgi immatrykulacyjnej dowiadujemy się, że wpisał się i uczęszczał na następujące zajęcia: filozofia państwa u prof. Stefana Pawlickiego (4 godz. tyg.), filozofia Arystotelesa u prof. Stefana Pawlickiego (1 godz. tyg.); Mickiewicz i Puszkin u prof. Józefa Tretiaka (4 godz. tyg.); wstęp do filologii słowiańskiej u prof. Józefa Tretiaka (2 godz. tyg.); seminarium słowiańskie u prof. Jana Łosia (2 godz. tyg.); czytanie nowel Turgieniewa u prof. Włodzimierza Nakoniecznego; polscy pisarze polityczni u prof. Stanisława Tarnowskiego (2 godz. tyg.); pesymizm w literaturze XIX wieku u prof. Mariana Zdziechowskiego (1 godz. tyg. $)^{4}$. Zamieszkał w domu przy ul. Garncarskiej 24. Jak wynika z niektórych źródeł, do Krakowa trafił z rekomendacji słoweńskich kręgów katolickich. $Z$ tego samego poręczenia znalazł się w Warszawie, prowadząc, jak sam wspominał, pracę w miejscowych bibliotekach ${ }^{5}$.

Po powrocie do Lublany w roku 1908 Lenard rzucił się w wir pracy publicystycznej i naukowej, ogłaszając swoje artykuły z dziedziny filozofii, historii, slawistyki,

2 Autor nekrologu zamieszczonego w gazecie „Delo” Ivan Kleft podaje jako datę urodzin rok 1879 („Delo”, 28 I 1962). Podobną datę znajdujemy w maszynopisie biografii sporządzonej prawdopodobnie przez żonę Lenarda i załączonej do jego spuścizny przekazanej do Narodnej in Univerzitetnej Knjižnici. Narodna in Univerzitetna Knjižnica, Rokopisna zbirka (dalej: NUK), Ms. 1880: Zapuščina L. Lenarda, nr 1: Biografska skica; zob. Archiwum Uniwersytetu Jagiellońskiego (dalej: AUJ), sygn. WF II 504: Teczki akt doktorskich, [L. Lenard], Curriculum vitae; M. Tominšek, Leopold Lenard (1876-1962), katloliški teolog, filozof, novinar in kulturni delavec, „Bogoslovni vestnik” 2002, t. 62, nr 4, s. 613.

3 AUJ, sygn. S II 188: Katalog główny studentów UJ za rok szkolny 1906/07, filozofia I; studenci zwyczajni, poz. 2801; Corpus studiosorum Universitatis Iagellonicae in seculi XVIII-XX, t. 3: $K-L$, Kraków 2009; zob. B. Oczkowa, Lénardov „Rozwój historyczny gramatyki słoweńskiej”. Prispevek $k$ zgodovini slovenskega jezikoslovja [w:] Obdobje simbolizma v slovenskem jeziku, književnosti in kulturi, 2. del. Mednarodni simpozij v Ljubljani od 1. do 4. Julija 1982, Ljubljana 1983, s. 295, 302; I. Gantar Godina, Dr. Leopold Lenard, „Zgodovinski časopis”, R. 46, 1992, nr 3, s. 395.

${ }_{4}$ AUJ, sygn. WF II 344: Katalog studentów i studentek zwyczajnych i nadzwyczajnych, oraz studentów farmacji i rolnictwa zwyczajnych i nadzwyczajnych z roku akademickiego 1906/07 I półrocze, poz. 325; B. Oczkowa, op. cit., s. 296, 302.

5 AUJ, sygn. WF II 504, [L. Lenard], Curriculum vitae; A. Pirjevec, Slovenski biografski leksikon, Ljubljana 1925-1932, s. 634; V. Molé, Iz knjige spominov, Ljubljana 1970, s. 57. 
a także literacko-krytyczne w takich czasopismach, jak: „Dom in svet”, „Slovenec”, „Čas”, „Slovenski gospodar”, „Zora”, „Domoljub” i innych. Większą część swojej bogatej twórczości i działalności w początkach XX wieku poświęcił idée fixe swego życia, to jest idei wszechsłowiańskiej i współpracy pomiędzy narodami słowiańskimi.

W kwietniu 1910 roku Lenard zjawił się w Krakowie i złożył podanie oraz stosowne dokumenty na Wydziale Filozoficznym Uniwersytetu Jagiellońskiego z prośbą o zezwolenie na składanie egzaminów doktorskich z filologii słowiańskiej i filozofii, dołączając rękopis rozprawy doktorskiej pt. „Vzajemnost slovanska v literaturi slovenski”. W recenzji dysertacji promotor prof. Jan Łoś zwracał wprawdzie uwagę na pewien niedostatek ogólnych sądów, ale podkreślał wagę „pierwiastków trwałych”, jak chociażby podniesienie kwestii bogomiłów wśród Słoweńców. Z uznaniem wypowiadał się o wysiłku heurystycznym autora i wadze zebranego materiału, który „może się stać podstawą do dalszych badań”. Opinię tę powtarzał drugi recenzent prof. Jan Rozwadowski. Obie recenzje zamykał wniosek o dopuszczenie do składania ustnych rygorozów ${ }^{6}$. W dniu 14 lipca 1910 roku Lenard złożył pisemny egzamin doktorski z językoznawstwa porównawczego i filologii klasycznej przed komisją złożoną z profesorów: Kazimierza Morawskiego, Jana Łosia i Jana Rozwadowskiego. Drugi złożył z filozofii w dniu 28 czerwca 1910 roku przed komisją w składzie: prof. Maurycy Straszewski i prof. Stefan Pawlicki ${ }^{7}$. Promocja doktorska odbyła się w dniu 29 lipca 1910 roku w obecności rektora UJ prof. Józefa Łazarskiego, dziekana Wydziału Filozoficznego prof. Henryka Hoyera i promotora prof. Jana Łosia ${ }^{8}$.

W latach I wojny światowej Lenard pracował jako kapłan w miejscowości Borovica, po czym został proboszczem w Slapie koło Vipavy na słoweńskim Primorju. Po zakończeniu wojny w roku 1918 znalazł się w Mariborze, gdzie wydawał czasopismo katolickie i przewodniczył stowarzyszeniu słoweńskich uchodźców z Włoch i Karyntii pod nazwą „Jugoslovanska matica”. W roku 1920 wydał książkę pod tytułem Jugoslovanski Pijemont, w której, pisząc w duchu jugosłowiańskim, starał się przybliżyć Słoweńcom historię i kulturę Serbii 9

W roku 1921, porzuciwszy stan duchowny, przeniósł się do Belgradu. Powody tej zaskakującej decyzji nie są bliżej znane, ale - jak przypuszczają niektórzy biografowie - miało to związek z niegodzeniem się Lenarda z katolickim klerykalizmem. Wkrótce związał się z Serbską Partią Radykalną Nikoli Pašicia ${ }^{10}$. Został zatrudniony w Ministerstwie Spraw Zagranicznych w wydziale informacji. Jego praca na stanowisku referenta, którą wykonywał przez 20 lat, i którą określał jako „poniżającą”,

6 AUJ, sygn. WF II 504, nr 376, Podanie Lenarda do Wydziału Filozoficznego UJ z 20 IV 1910; ibidem, Recenzja prof. prof. J. Łosia i J. Rozwadowskiego, 27 V 1910.

7 Ibidem, sygn. WF II 508: Album Doctorum Philosophiae z lat 1888-1927, s. 106; ibidem, sygn. S II 521: Liber Promotionum Universitatis Iagellonicae 1910-1920, poz. 3667.

8 NUK, Ms. 1880, Oryginał dyplomu doktorskiego L. Lenarda uzyskanego w UJ. Kopia tegoż dyplomu znajduje się w Archiwum UJ. Słoweńscy autorzy artykułów poświęconych L. Lenardowi pomijają ten istotny szczegół, jakim było uzyskanie doktoratu w UJ. Wspomina o tym jedynie I. Kleft w nekrologu, ale bez podania daty.

9 A. Pirjevec, op. cit., s. 634; I. Gantar Godina, Dr. Leopold Lenard, s. 393; M. Tominšek, op. cit., s. 614-615.

10 I. Kleft, op. cit.; M. Tominšek, op. cit., s. 616. 
polegała na tłumaczeniu artykułów z prasy zagranicznej (znał 10 języków nowożytnych!) ze specjalnością spraw czeskich i polskich ${ }^{11}$.

Mieszkając w Belgradzie, zachował bliskie kontakty ze Słowenią, redagując czasopismo „Samouprava”, organ młodzieży narodowo-radykalnej wydawany w latach 1922-1923 w Gornjej Radgonie. W roku 1921 Lenard utworzył w Belgradzie Towarzystwo Przyjaciół Polski, obejmując w nim funkcję członka zarządu. Pisywał swoje artykuły we francuskojęzycznym czasopiśmie „Message Polonais” oraz w wydawanym w Gdyni „Baltische Presse” ${ }^{12}$. Kiedy w roku 1928 we Lwowie rozpoczęto wydawanie poświęconego sprawom słowiańskim czasopisma „Ruch Słowiański” pod redakcją Tadeusza Lehra-Spławińskiego, Komitet Redakcyjny zwrócił się do Lenarda z prośbą o nadsyłanie artykułów i recenzji na temat „realnych podstaw łączności Słowian”, uwzględniając w szczególności takie kwestie, jak: „1. Wspólność krwi i rasy, 2. Problem jedności kulturalnej, 3. Sprawy unifikacji alfabetu, 4. Czy zachodzi potrzeba obrania języka ogólno-słowiańskiego, 5. Przeszkody łączności Słowian”'13. Lenard był ponadto korespondentem „Prager Presse” i opublikował szereg artykułów w prasie jugosłowiańskiej, dotyczących historii i kultury Czechosłowacji. W latach 30. XX wieku założył w Belgradzie Towarzystwo Przyjaciół Serbów Łużyckich i wydał dwie książki poświęcone historii i literaturze tego słowiańskiego narodu.

W Belgradzie Lenard przebywał do przejścia na emeryturę w roku 1936, po czym przeniósł się do Zagrzebia. Tam pozostał aż do czasu okupacji niemieckiej w roku 1941. Z ramienia lewego skrzydła ugrupowania Seljačka demokratska koalicija utrzymywał związki ze słoweńską opozycją, w której czołową rolę odgrywała partia komunistyczna. Do roku 1941 utrzymywał również kontakty z organizacją polityczną o nazwie Slovensko kmečko-delavsko gibanje ${ }^{14}$. Z powodu ulotek tej organizacji, które Lenard dał wydrukować w zagrzebskiej drukarni Grafika, został aresztowany przez gestapo w Belgradzie czerwcu 1942 roku i skazany na śmierć przez rozstrzelanie. Śmierci uniknął dzięki wstawiennictwu swojego przyjaciela, po czym schronił się w głębi Serbii. Po wyzwoleniu Jugosławii w roku 1945 znalazł się ponownie w Wydziale Informacji MSZ, kierowanym przez Savę Kosanovicia. Nowa komunistyczna władza nie była mu przychylna i Lenard otrzymał zajęcie podobne jak przed wojną. Utraciwszy w końcu pracę i pozostając bez zajęcia, wiódł dalej żywot - jak pisał - „zgrzybiałego człowieka” odseparowanego od społeczeństwa. O swoim wcześniejszym zaangażowaniu w życie społeczne, kontaktach ze sferami dyplomatycznymi i działalności w licznych organizacjach wspominał z goryczą pod koniec życia ${ }^{15}$. Umarł w osamotnieniu 26 stycznia 1962 roku, mając u swego boku

11 List Lenarda do V. Bučara z 17 V 1959 [w:] V. Bučar, Samoizpoved Dr. Leopolda Lenarda, „Meddobje” (Buenos Aires), R. 13, 1973, nr 1, s. 74; M. Tominšek, op. cit., s. 616.

12 NUK, Ms. 1880, Biografska skica, s. 1; I. Kleft, op. cit.; M. Tominšek, op. cit., s. 616.

13 NUK, Ms. 1880, fasc. III. Korespondencija, Komitet Redakcyjny Ruchu Słowiańskiego do Lenarda, I 1928; ibidem, Redakcja Ruchu Słowiańskiego do L. Lenarda, III 1929; ibidem, J. Richter do L. Lenarda, 8 II 1929.

${ }_{14}$ I. Kleft, op. cit.; M. Tominšek, op. cit., s. 616; I. Gantar Godina, Dr. Leopold Lenard, s. 396.

15 „Sedaj niti ne vem, kje se nahajajo njihove ambasade, a dalje od vratarja v teh gotovo ne bi prišel... Sedaj ne vem nobeno društvo, ne tuje ne domače" (List Lenarda do V. Bučara, 17 V 1959 [w:] V. Bučar, op. cit., s. 75. 
jedynie swoją żonę Radmilę, która całość jego spuścizny przekazała do Narodowej i Uniwersyteckiej Biblioteki w Lublanie.

\section{WIZJE PRZYSZŁOŚCI SŁOWIAN I AUSTRII}

W całej bogatej twórczości i działalności Leopolda Lenarda, która obejmowała zagadnienia polityczne, społeczne, kulturalne i religijne, wyróżnia się jeden temat, którym zajmował się przez całe swoje życie, któremu poświęcił swoją dysertację doktorską i znaczną część swych prac. Była nim idea słowiańska, zakładająca współpracę pomiędzy Słowianami, z podkreśleniem utrzymania jak najbliższych związków z Polakami ${ }^{16}$. Okazją do bliższego poznania historii i stosunków polskich, a także do nauki języka polskiego i ukraińskiego, stały się studia na Uniwersytecie Lwowskim w latach 1903-1904, ale niewątpliwie największe znaczenie miały tu studia na Uniwersytecie Jagiellońskim w Krakowie i kontakty z krakowskim środowiskiem slawistycznym i historycznym, skupionym w istniejącym od roku 1901 Klubie Słowiańskim i wokół ukazującego się od roku 1905 czasopisma „Świat Słowiański”.

Jeszcze przed przybyciem Lenarda do Krakowa jesienią 1906 roku ukazała się w Celju jego anonimowa broszura pt. Der Panslawismus. Eine national-politische Betrachtung, która w sposób szczegółowy przedstawiała problem słowiańskiej wzajemności, istotę panslawizmu, wyrażającego się w uznaniu przywódczej roli Rosji, a także kwestię związania się Słowian austriackich z Rosją. Lenard zwracał na wstępie uwagę na zmieniającą się sytuację polityczną, między innymi na wydarzenia w Rosji i zapowiedź przyznania w Austrii powszechnego prawa wyborczego, które rodzą potrzebę stworzenia planu współpracy Słowian. Zauważał przy tym, że wyłożony w broszurze program jest już propagowany przez różne środowiska, między innymi wśród Polaków reprezentuje go Klub Słowiański i wydawany przezeń „Świat Słowiański”. Wzajemność słowiańska nie mogła, zdaniem Lenarda, być pustym frazesem, ale powinna była przybrać formę konkretnego programu ${ }^{17}$. Lenard podkreślał dobitnie, że Polacy przejawiają wśród wszystkich Słowian największą polityczną dojrzałość, jaką nabyli w trakcie swojej tragicznej, ale pełnej chwały, historii. Posiadają

16 I. Gantar Godina, Dr. Leopold Lenard, s. 396; M. Tominšek, op. cit., s. 617-618. Ze współczesnej, obszernej literatury polskiej dotyczącej idei słowiańskiej zob. M. Bobrownicka, Narkotyk mitu. Szkice o świadomości narodowej i kulturowej Stowian Zachodnich i Potudniowych, Kraków 1995; eadem, Lud - naród - społeczeństwo. Kategorie zbiorowej tożsamości w odrodzeniu Słowian habsburskich, „Pamiętnik Słowiański”, t. 52, 2002, s. 3-20; J. Rapacka, Godzina Herdera. O Serbach, Chorwatach i idei jugosłowiańskiej, Warszawa 1995; eadem, Śródziemnomorze - Europa Bałkany. Studia o literaturach południowosłowiańskich, Kraków 2002; L. Moroz-Grzelak, Bracia Stowianie. Wizje wspólnoty w rzeczywistości, Warszawa 2013. Spośród autorów obcych zob. również: I. Gantar-Godina, Slovanska vzajemnost in Slovenci [w:] Zbornik zborovanja slovenskih zgodovinarjev 27 IX-1 X 1994, red. A. Gabrič, Ljubljana 1994, s. 82-86; J. P ešina, Stowianie poludniowi w koncepcji wzajemności słowiańskiej Karela Havlička Borovskiego, „Prace Historyczne” 2010, nr 137, s. 89-96.

17 [L. Lenard], Der Panslawismus. Eine national-politische Betrachtung, Cilli 1906, s. 4-5, 36-38. 
jak żaden inny naród słowiański takie cechy, jak: indywidualna moralność, powaga charakteru, wysokie ideały, trwałość dążeń. Są więc, zdaniem Lenarda, „z powodu swojej przeszłości, swojego położenia geograficznego i cech charakteru najbardziej powołani do tego, aby poprowadzić wielką walkę Słowiańszczyzny przeciwko furor teutonicus"18.

Przechodząc do stosunków polsko-rosyjskich, Lenard z jednej strony przyznawał, że Rosja posiada w Słowiańszczyźnie ogromny kapitał i prowadzenie jakiejkolwiek polityki przeciwko niej byłoby samobójstwem, ale z drugiej strony dowodził, iż polityka Rosji względem Polaków, ich rusyfikacja jest pod wieloma względami niemądra i szkodzi Słowianom. W konkluzji stwierdzał, że jedynym wyjściem byłoby przyznanie Królestwu Polskiemu możliwie jak najszerszej autonomii, a Polakom w innych prowincjach rosyjskich pełnej swobody w powoływaniu do życia stowarzyszeń, czasopism itp. Tym sposobem Rosja zapobiegnie wielkiemu niebezpieczeństwu grożącemu jej ze strony niemieckiego naporu, będzie się mogła rozwijać, a Słowiańszczyzna zyska w niej trwałe oparcie. Szeroka autonomia Królestwa Polskiego stałaby się podstawą do polsko-rosyjskiego porozumienia. Polacy musieliby jednak odrzucić swój „ekspansywny narodowy plan” wskrzeszenia niezależnego państwa od morza do morza i zrezygnować z myśli rewanżu. Utworzenie autonomicznego Królestwa Polskiego (na wzór Bawarii w Niemczech) leży, według Lenarda, w interesie Rosji i całej Słowiańszczyzny i musi stanowić punkt wyjścia polityki wszechsłowiańskiej. Równocześnie solidarność Polaków z zachodnimi i południowymi Słowianami, w powiązaniu z nową sytuacją polityczną w Europie, będzie stanowić dla nich gwarancję, że nigdy nie ulegną przemocy ze strony Rosji ${ }^{19}$. Uczynienie tego pierwszego kroku, jakim jest przyznanie Polsce autonomii, otworzy drogę do stworzenia szerokiej wszechsłowiańskiej polityki. Polacy, przypominał raz jeszcze Lenard, mają największą polityczną wiedzę i największe historyczne doświadczenie. Dzięki temu przyjdzie im najłatwiej spośród wszystkich Słowian stworzenie dobrze zorganizowanego państwa. Znajdzie to też odzwierciedlenie w polityce zewnętrznej. Rozwój materialny Królestwa Polskiego jako forpoczty i bastionu Słowiańszczyzny przeciwko naporowi niemieckiemu przyniesie jej korzyści. Polacy będą bowiem działać na rzecz stworzenia unii celnej pomiędzy Austrią i Rosją, a jednocześnie będą pośredniczyć w stosunkach austriacko-rosyjskich, a także francusko-angielskich. Drugim krokiem tej, jak to nazywał Lenard, Etappenpolitik, będzie utworzenie związku Austrii, Rosji i Francji przy zachowaniu przyjaznych stosunków z Włochami i Anglią. W ten sposób odżyłyby dawne idee Wenzla Antona von Kaunitza i Marii Teresy ${ }^{20}$.

Gdy Austria uwolni się od niemieckiej hegemonii i zacznie jednakowo traktować wszystkich swoich obywateli, oznaczać to będzie przyjęcie przez nią nowego słowiańskiego oblicza (neue, slawische Physionomie). Upadnie system dualistyczno-centralistyczny i Austria przybierze kształt „,narodowo-federalistyczny” o przeważająco słowiańskim charakterze. Idea wielkoniemiecka Drang nach Osten zagraża,

18 [L. Lenard], Der Panslawismus..., s. 50; M. Tominšek, op. cit., s. 618.

19 [L. Lenard], Der Panslawismus..., s. 55; M. Tominšek, op. cit., s. 618-619.

20 [L. Lenard], Der Panslawismus..., s. 56-57. 
zdaniem Lenarda, egzystencji Austrii ${ }^{21}$. Widać tu wyraźne nawiązanie do rozwijanej już od lat 40. XIX wieku wśród Słowian habsburskich idei austroslawizmu, federalizmu, a na przełomie XIX i XX wieku trializmu ${ }^{22}$. Izolowanie Niemiec i stworzenie silnego sojuszu przeciwko nim przyniesie korzyści, a w historii powszechnej zostanie to zapisane jako „nowy Grunwald”. To zwycięstwo będzie oznaczało przyłączenie Śląska, Poznańskiego i części Prus do Królestwa Polskiego. Austria będzie mogła wówczas ustąpić z Galicji na rzecz Królestwa Polskiego i znaleźć sobie pewną rekompensatę na Bałkanach aż po Saloniki, a może i Konstantynopol. Trójporozumienie Rosji, Polski i Austrii stałoby się ostoją pokoju światowego, nastąpiłoby rozbrojenie i zbratanie narodów ${ }^{23}$. Pierwszym krokiem do realizacji tego programu powinno być, zdaniem Lenarda, założenie własnego organu na wzór na przykład petersburskiego „Kraju”, a drugim stworzenie organizacji ${ }^{24}$.

Broszura Lenarda została powitana $\mathrm{z}$ wielkim entuzjazmem w krakowskim środowisku Klubu Słowiańskiego i jego organu „Świata Słowiańskiego”. Zapowiedź jej ukazania się przynosił „Świat Słowiański” we wrześniowym zeszycie roku 1906 w rubryce Kronika. Redakcja nie wiedziała jeszcze, czy autor broszury podpisze się pod nią, ale podkreślała, że miał on wcześniej sposobność poznać Polaków, a wiosną 1906 roku bawił w Krakowie i Zakopanem. Zwracała uwagę, że ogólnosłowiański program autora broszury jest całkowicie zgodny z programem „Świata Słowiańskiego”, a jej autor „wzywa wprost Polaków, aby stanęli na czele ruchu słowiańskiego ${ }^{25}$. Szczegółowe omówienie broszury Lenarda zamieścił „Świat Słowiański” w październikowym zeszycie z roku 1906 pt. Program stowieńskiego patrioty, a zostało ono skreślone prawdopodobnie ręką redaktora naczelnego Feliksa Konecznego. Na wstępie autor przypominał, że zaprezentowany w broszurze program, mogący stać się powszechnym słowiańskim, powstał w Krakowie. Wytyka trzy wady broszury: język, anonimowość i tytuł. Zamiast języka niemieckiego, który jest nieprzystępny dla większości, Słowian, proponuje praktyczniejszy francuski, ale byłoby najlepiej, gdyby został napisany w języku ojczystym publicysty. „Anonimowość może podniecać ciekawość, ale rzeczy samej nigdy nie pomaga" - stwierdzał autor omówienia.

21 Ibidem, s. 57-58.

22 Z obszernej literatury przedmiotu podajemy wybrane pozycje: H. Rumpler, Eine Chance für Mitteleuropa. Bürgerliche Emanzypation und Staatsverfall in der Habsburgermonarchie. Österreichische Geschichte 1804-1914, Wien 1997; [A. Moritsch], Austroslavismus. Ein verfrüchtes Konzept zur politischen Neugestaltung Mitteleuropas, Wien-Köln-Weimar 1996; H. Wereszycki, Pod bertem Habsburgów. Zagadnienia narodowościowe, Kraków 2015; A. Giza, Austroslawizm w XIX wieku, „Przegląd Zachodniopomorski” 1993, z. 1, s. 109-120; A. Cetnarowicz, Koncepcje federalistyczne wśród Stowian poludniowych (do roku 1914) [w:] Europa unii i federacji. Idea jedności narodów i państw od średniowiecza do czasów wspótczesnych, red. K. Ślusarek, Kraków 2004, s. 259-272; idem, Stoweńskie programy narodowe do roku 1914, „Prace Komisji Środkowoeuropejskiej PAU”, t. 1, 1993, s. 35-50; A. Cetnarowicz, Die proösterreichische Einstellungen bei den Polen in der zweiten Hälfte des 19. Jahrhundert [w:] Der Erste Weltkrieg und der Vielvölkerstaat, Wien 2012, s. 11-22; S. F al kovič, Die polnische Nationalbewegung zwischen Panslavismus, Pangermanismus und Austroslavismus [w:] Osteuropäische Geschichte in vergleichender Sicht, hrsg. M. Müller, Berlin 1996, s. 255-270.

23 [L. Lenard], Der Panslawismus..., s. 60-61.

24 Ibidem, s. 67.

${ }^{25}$ Kronika, „Świat Słowiański”, R. 2, t. 2, 1906, s. 238. 
Zwracał również uwagę na niestosowny i niefortunnie dobrany tytuł Panslawismus, co rodzi domysł, że chodzi tu o panslawizm w rosyjskim znaczeniu słowa, a więc o podporządkowanie wszystkich Słowian Rosji. Autor artykułu streszczał pokrótce te fragmenty broszury, które odnosiły się do sytuacji Słoweńców, zwracając uwagę nie tylko na zagrożenie niemieckie, ale także na niepewność co do poparcia ze strony innych Słowian, między innymi Rusinów i Chorwatów. Przechodząc do omówienia części broszury odnoszącej się do stosunków polsko-rosyjskich, podkreślał najważniejsze myśli mówiące o potrzebie przyznania przez Rosję jak najszybciej Królestwu Polskiemu autonomii, która powinna się stać „podstawą porozumienia polsko-rosyjskiego" ${ }^{26}$. Rozstrzelonym drukiem podkreślał autor stwierdzenie, że utworzenie autonomicznej Polski musi stanowić punkt wyjścia polityki ogólnosłowiańskiej. Podsumowując Etappenpolitik Lenarda, autor artykułu eksponował rolę, jaką ma do odegrania Austria, która, chociaż znienawidzona obecnie przez Słowian południowych, ,nadaje się pomimo wszystko na jedyny czynnik mogący najłacniej urzeczywistnić ideę jugosłowiańską". Marsz do Konstantynopola pozostawiał autor „poza horyzontem politycznego kombinowania” raczej dla następców. Końcowe uwagi odnosiły się do programu działania, założenia czasopisma i stworzenia organizacji. Autor artykułu sugerował, aby czasopismo to wydawane było w czterech językach: chorwackim lub słoweńskim, czeskim, polskim i rosyjskim. Z satysfakcją konstatował, że polski sposób pojmowania idei słowiańskiej znalazł uznanie i oddźwięk wśród naszych południowych pobratymców, chociaż, jak dodawał, broszura powstała zupełnie samodzielnie, niezależnie od Krakowa i Petersburga. Najbardziej satysfakcjonował autora wspólny punkt wyjścia, jakim jest „patriotyzm narodowy"27.

Redakcja „Świata Słowiańskiego”, doceniając wagę i znaczenie broszury Lenarda, „w której stawia tak wysoko misję narodu polskiego w Słowiańszczyźnie”, zamieściła w kilka miesięcy później artykuł słoweńskiego duchownego pt. Polityczne zadanie Polaków $w^{28}$. Lenard na wstępie stwierdzał, że przeszkodę w przyznaniu przez Rosję szerokiej autonomii dla Królestwa Polskiego stanowi polityka Niemiec, której państwo carów ulega i zarazem się obawia. Uzyskanie przez Polaków szerokich swobód pociągnęłoby za sobą, zdaniem Lenarda, okupację kraju przez Niemcy. W żywotnym interesie Austrii leży zatem niedopuszczenie do tego, a także do gospodarczego uzależnienia Rosji od Niemiec, co zagrażałoby samodzielności Austrii i jej wpływowi na Bałkanach. Tak więc, konkludował Lenard, jest „zarówno w interesie Austryi troszczyć się o interesy polskie, jak i w interesie Polski utrzymać Austrię samodzielną i wpływową [...] interes [...] Polaków i dobrze zrozumiany interes Austrii uzupełniają się wzajemnie. W tym leży klucz przyszłej polityki słowiańskiej w ogóle, a polskiej w szczególności". Warunkiem jest, dowodził Lenard, uwolnienie się Austrii od hegemonii Niemiec i roli „bursza-sekundanta” oraz oparcie się na swej naturalnej podstawie, jaką winna być konfederacja narodów ${ }^{29}$. Taka Austria mogłaby

26 Program słowieńskiego patrioty, „Świat Słowiański”, R. 2, t. 2, 1906, s. 275.

27 Ibidem, s. 277-278.

28 L. Lenard, Polityczne zadanie Polaków, „Świat Słowiański”, R. 3, t. 1, 1907, s. 177-184.

29 Ibidem, s. $177-180$. 
się skutecznie przeciwstawić ekspansji Niemiec na Wschód, a zatem również ewentualnej okupacji Królestwa Polskiego.

Zadaniem Polaków obecnie jest tedy przykładać się usilnie do tego, żeby z Austrii wytworzyła się przeciwwaga wobec Niemiec. A stanowi to zarazem żywotny interes państwa austriackiego i wszystkich austriackich ludów, a nawet słowiańskiego Bałkanu. Tym sposobem zgadzają się najpełniej interesy polskie z interesami austriackich Słowian i skoro tylko Polacy zrozumieją swoją rolę, znajdą we wszystkich nie-niemieckich ludach Austrii naturalnych sprzymierzeńców ${ }^{30}$.

Lenard dobitnie podkreślał, że ,„polityka słowiańska jest niemożliwą przeciw Polsce i bez Polski”. Warunkiem jej powodzenia, a zarazem punktem wyjścia jest złamanie hegemonii niemieckiej Austrii. Najbliższym celem powinna być zatem reorganizacja Austrii, a pierwszym krokiem reforma wyborcza. Zadaniem Słowian, kontynuował Lenard, jest usilne dążenie do tego, aby „we wszystkich dziedzinach państwowych wybił się bardziej słowiański charakter Austryi”. Pozbawione poparcia Austrii Cesarstwo Niemieckie przestanie wywierać swój wpływ na Rosję, a wtedy Polacy w Królestwie otrzymają szansę wywalczenia autonomii własnymi siłami. Autonomia Królestwa Polskiego spowoduje z kolei ,wybicie się słowiańskiego charakteru [Austrii] i przyjście do skutku przymierza Austrii z Rosją (a dalej z Francją i Anglią") ${ }^{31}$. Lenard po raz kolejny mocno wybijał współzależność polityki polskiej i słowiańskiej, podkreślając, że programu ,narodowego wyzwolenia i politycznej samodzielności Czech i Słowian południowych bez udziału Polaków nie podobna przeprowadzić". Warunkiem wstępnym jest dla niego rozszerzenie i pogłębienie przez Polaków swojego programu narodowego i pełniejsze zrozumienie dla programu słowiańskiego, który nie znajduje jeszcze uznania u wszystkich stronnictw politycznych. Lenard podawał tu jako przykład stronnictwo wszechpolskie, co redakcja „Świata Słowiańskiego” podważała w przypisie, stwierdzając: „,gdyby którekolwiek ze stronnictw polskich chciało zająć dzisiaj stanowisko wrogie wobec idei polsko-słowiańskiej, podkopałoby się samo na jutro" ${ }^{32}$. Na koniec Lenard dotykał drażliwego problemu stosunku Polaków i innych Słowian do Rosji. Przyznawał, że istnieje na tym tle wiele nieporozumień. Uważał, że w okresie odrodzenia narodowego w XIX wieku Czesi i Słowianie południowi ulegli pewnej fascynacji potęgą Rosji i zaprzepaścili szansę stworzenia słowiańskiego programu politycznego oraz przejęcia roli pośrednika pomiędzy Rosją a Polską. Polacy mają więc, zdaniem Lenarda, prawo żądać od Czechów i Słowian południowych zrewidowania swoich poglądów, ,ale nie mogą wymagać, abyśmy podzielali wszystkie ich uczucia". Powinni wyzbyć się pewnych uprzedzeń i małoduszności i ,okazywać nam więcej zrozumienia, dać możliwość wzajemnego otwartego wypowiedzenia się, a przede wszystkim pilniej badać stosunki słowiańskie"33.

\footnotetext{
30 Ibidem, s. 181.

31 Ibidem, s. 182.

32 Ibidem, s. 184.

33 Ibidem.
} 


\section{ROSJA I STOSUNKI POLSKO-ROSYJSKIE}

Problemowi stosunków polsko-rosyjskich, odgrywających kluczową rolę w wytyczeniu nowej polityki ogólnosłowiańskiej, poświęcił Lenard wiele miejsca. Nie ulega wątpliwości, że jego poglądy ukształtowały się w dużej mierze pod wpływem ideologii i programu reprezentowanego i głoszonego przez krakowskie środowisko związane z Klubem Słowiańskim (później Towarzystwem Słowiańskim) i jego organem „Światem Słowiańskim”. Lenard należał do nielicznych spośród Słoweńców, którzy dostrzegali w konflikcie polsko-rosyjskim związek z interesami niemieckimi. Jego poglądy w tej kwestii pokrywały się z linią ideową programu słowiańskiego, głoszonego przez Mariana Zdziechowskiego i Feliksa Konecznego ${ }^{34}$.

Lenard znał pracę Zdziechowskiego Die Grundprobleme Russlands wydaną w Wiedniu w roku 1907. Na łamach czasopisma „Dom in svet”, którego był współredaktorem, ogłosił obszerną jej recenzję, podkreślając wielkie zalety książki dla zrozumienia Rosji. Książka składa się, zdaniem Lenarda, z głęboko przemyślanych i według jednego filozoficzno-politycznego systemu napisanych artykułów stanowiących podstawę, na której kontynuatorzy będą mogli zbudować wśród Słowian ruch polityczny. Nicią przewodnią książki Zdziechowskiego jest, według Lenarda, wyjaśnienie problemu stanowiska Rosji wobec cywilizacji europejskiej. Lenard wydobywał z książki i omawiał te fragmenty, które mówią o wprowadzeniu w Rosji biurokratycznego, opartego na wzorach niemieckich systemu, o prześladowaniu Polaków i popieraniu antypolskiej polityki Niemiec, obcej także Słowianom austriackim i bałkańskim. Według Lenarda znaczenie książki Zdziechowskiego polega głównie na ukazaniu źródeł i rozwoju ,problemu rosyjskiego”. Lenard przedstawiał Zdziechowskiego jako założyciela Klubu Słowiańskiego w Krakowie i czasopisma „Świat Słowiański" i nazywał go twórcą nowego słowianofilstwa, które posiada mocną podstawę i zdoła objąć szersze kręgi. Już tylko z tego powodu, kończył swą recenzję Lenard, powinien tę książkę przeczytać każdy Słowianin, któremu bliskie są polityczne problemy Słowiańszczyzny ${ }^{35}$.

W jednym z kolejnych numerów tegoż pisma Lenard zamieścił recenzję książki Władimira Francewa Polskoje stawianowiedienije konca XVIII i pierwoj czetwierti XIX st. wydanej w Pradze w 1906 roku Lenard podkreślał, że w historii początków słowianoznawstwa zasługi polskich jego przedstawicieli są wciąż mało znane, zwłaszcza gdy mowa o ich uczestnictwie w ruchu odrodzeniowym Słowian na początku XIX wieku. Sprzeciwiał się rozpowszechnianemu czasem twierdzeniu, że Polacy w ogóle nie uczestniczyli w tym ruchu, albo że rola polskich uczonych była w tym ruchu nieznaczna. Jego zdaniem nie można przemilczeć zasług dla rozwoju słowianoznawstwa takich polskich uczonych, jak Bogumił Linde, Samuel Bandtkie, Wawrzyniec Surowiecki, Walenty Skorochod Majewski, Ignacy Rakowiecki, Michał

34 Zob. P. Biliński, Feliks Koneczny (1862-1949). Życie i działalność, Warszawa 2001, s. 79-98; I. Gantar Godina, Dr. Leopold Lenard, s. 397.

35 L. Lenard, Prof. dr. Maryan Zdziechowski: Die Grund-probleme Russlands. Akademischer Verlag, Wien 1907 [recenzja], „Dom in svet”, R. 20, 1907, nr 10, s. 477-478. 
Bobrowski. Od samego początku, dowodzi Lenard, polscy uczeni czuli potrzebę i rozumieli wagę większego zbliżenia zarówno z przedstawicielami filologii słowiańskiej na Zachodzie, jak i z uczonymi czeskimi i rosyjskimi. Wydawało im się to najlepszym środkiem wiodącym do przebudzenia własnego narodu, a wielu z nich uważało wręcz, że Polska będzie się mogła odrodzić tylko w związku z całym światem słowiańskim, kiedy włączy się do ruchu słowiańskiego. Lenard kończył swoją recenzję uwagą podkreślającą wielkie znaczenie książki Francewa nie tylko dla samych Polaków, ale również dla wszystkich Słowian, jako przyczynek do historii ich odrodzenia narodowego ${ }^{36}$.

W centrum uwagi Lenarda po powrocie do Lublany w roku 1908 pozostawała nadal idea wzajemności słowiańskiej, szeroko dyskutowana w całym świecie słowiańskim po kongresie neoslawistycznym w Pradze. Najwięcej miejsca poświęcał Lenard w tym czasie sprawie porozumienia polsko-rosyjskiego, dobrze rozumiejąc, że stanowi ono jedno z kluczowych problemów pomyślnego rozwoju ruchu wszechsłowiańskiego. W czasopiśmie „Čas” ukazał się w roku 1909 jego artykuł pt. Nekaj slovanskih vprašanj. Rusko-poljska sprava. Na wstępie Lenard określał spór polsko-rosyjski jako nie tylko polityczny, ale i historyczny. „Między Polakami i Rosjanami - pisał - stoi ściana nie do przebicia, różne kultury, z jednej strony bizantyjska z domieszką wpływów tatarskich, a z drugiej zachodnio-europejski katolicyzm" ${ }^{37}$. Na przeszkodzie porozumienia polsko-rosyjskiego stoi, zdaniem Lenarda, wszechwładna biurokracja obejmująca wszystkie dziedziny życia, która pilnie strzeże swoich interesów, również tych materialnych. Nie jest ona zainteresowana w doprowadzeniu do ugody polsko-rosyjskiej. Odwróciła się również od słowiańskiego programu, a rosyjski oficjalny panslawizm przekształcił się w ,,panazjatyzm”. A zatem, dowodził Lenard, aby ugoda polsko-rosyjska mogła dojść do skutku, rosyjska biurokracja „musi wykazać się patriotyzmem i poświęcić własne korzyści na ołtarzu ojczyzny”38. Ale obok tych wewnętrznych trudności istnieją jeszcze, według Lenarda, zewnętrzne, a jest nimi niemiecki wpływ na rosyjską biurokrację. „Dla Niemiec - pisał Lenard - jest żywotnym interesem, aby Polacy w zaborze rosyjskim byli prześladowani, dlatego biurokracja użyje całego swojego wpływu, aby nie doszło do porozumienia polsko-rosyjskiego". Pojawiające się czasem głosy o możliwości takiego porozumienia są, według niego, zwykłym oszustwem, a czasem wynikają z błędnego przenoszenia europejskich pojęć na Rosję ${ }^{39}$.

Pojawienie się ruchu neosłowiańskiego, przez Rosję nazywanego „nowym panslawizmem”, a przez Czechów „neoslawizmem”, oceniał Lenard krytycznie i określał to jako próbę ożywienia starego slawizmu. Patronują temu ruchowi czeskie

36 Idem, V. A. Francjev: Poljskoje slavjanovjedjenije konca XVIII. i pjervoj četvjerti XIX. stol. Praga češkaja. Tipografija „Politika” 1906 [recenzja], „Dom in svet”, R. 20, 1907, nr 12, s. 566-567.

37 L. Lenard, Nekaj slovanskih vprašanj. Rusko-poljska sprava, „Čas”, R. 3, 1909, s. 81; zob. I. Gantar Godina, Neoslavizem in Slovenci, Ljubljana 1994, s. 143-144; eadem, Novoslavenska ideja in Slovenci, „Zgodovinski časopis”, R. 43, 1989, nr 4, s. 538; eadem, Dr. Leopold Lenard, s. 397.

38 L. Lenard, Nekaj slovanskih vrpašanj..., s. 82-84; I. Gantar Godina, Neoslavizem in Slovenci..., s. 145.

39 L. Lenard, Nekaj slovanskih vprašanj..., s. 84. 
„Narodni listy”, główny organ „starego słowianofilstwa”, a także rosyjskie „Nowoje wriemia” i „Moskowskoje wiedomosti”. Program neoslawizmu nie wnosi, zdaniem Lenarda, nic nowego, jedynie powtarza stare hasło o Słowianach jako braciach. Akcentuje przy tym silnie tezę, że wzajemność słowiańska to wyłącznie idea kulturalna, a nie polityczna. Lenard dostrzegał w tym chęć „epigonów patriarchów starego rosyjskiego panslawizmu" - pozostawienie idei politycznej w tle, a głoszenie idei jedności kulturalnej. Nazywał to pozorem, wręcz nonsensem, gdyż kulturalnego zbliżenia Słowianom nie potrzeba. Cóż bowiem zyskaliby Słowianie z hasła kulturalnego zbliżenia z państwem, które dotąd przez wieki niszczyło kulturę, stwierdzał Lenard. W praktyce neoslawizm jest tylko epigonem starego panslawizmu ${ }^{40}$. Temu programowi przeciwstawiał Lenard program wszechsłowiański reprezentowany przez wydawany przez Adolfa Černego w Pradze „Slovanský Přehled”, ale przede wszystkim program krakowskiego „Świata Słowiańskiego”. Ten ostatni jest, według Lenarda, jedynym słowiańskim czasopismem, które ma jasny program i skupia najwybitniejszych „mężów narodu polskiego”. W pięciu punktach streszczał jego główne założenia:

1. Każdy naród słowiański sam decyduje o swoim obliczu, czy ma być klerykalnym, liberalnym czy socjalistycznym i żaden sąsiad nie może mu narzucać gotowych form. 2. Słowiańska wzajemność ma sens tylko w znaczeniu politycznym. Wzajemność kulturalna jest pustą frazą. 3. Punkt ciężkości Słowiańszczyzny nie leży w Rosji, ale w Austrii, a rosyjscy Słowianie są pod pewnymi względami bardziej prześladowanymi niż w Turcji. Może nadejdzie czas, kiedy Austria uwolni Rosję od absolutyzmu i biurokratyzmu. 4. Austria jako jedyna jest powołana zaprowadzić na Południu porządek i przynieść Słowianom południowym wspólne państwo. To nie z Serbii, ale z Austrii ma wypływać jugosłowiańska polityka. 5. Dualizm stanowi nienaturalną i nieudaną formę państwa austriackiego. Jedynym ustrojem zabezpieczającym jej egzystencję i potrzeby jest federalizm ${ }^{41}$.

Program ten, stwierdzał Lenard, nie jest antyaustriacki, lecz przeciwnie wielkoaustriacki, nie jest jednocześnie antyrosyjski, gdyż obiecuje narodowi rosyjskiemu wolność w federacji z Austrią. Nie jest też nieprzyjazny Jugosłowianom, przeciwnie obiecuje im ,zjednoczenie w wyższej kulturze”. Tylko na podstawie tego politycznego programu możliwe staje się działanie w duchu kulturalnej i gospodarczej wzajemności, kończył swój wywód Lenard ${ }^{42}$.

W jednym ze swoich artykułów opublikowanych na łamach czasopisma „Dom in svet” w roku 1909 Lenard poruszał sprawę stosunków polsko-rosyjskich, ale widzianych pod kątem wyznaniowym. Opisuje w nim prześladowania ludności katolickiej na Podlasiu i trwającą 30 lat bezpardonową walkę władz z ,upornikami”. Rosyjskiemu terminowi prawosławie przeciwstawiał polskie, katolickie wyznanie, które nazywal „poljasztwo"43.

Do zagadnienia tego powrócił Lenard w roku 1912, w czasie gdy rosyjska Duma rozpoczęła obrady nad projektem utworzenia nowej guberni chełmskiej. Nakładem

\footnotetext{
40 Ibidem, s. 85-86.

41 Ibidem, s. 86.

42 Ibidem, s. 86; I. Gantar Godina, Novoslovanska ideja..., s. 539.

43 L. Lenard, Na slovanski zemlji. Skice z pota, „Dom in svet”, R. 22, 1909, nr 3, s. 125-129.
} 
Towarzystwa Przyjaciół Narodu Polskiego w Lublanie ukazała się jego broszura pt. Krvav list iz zgodovine ruskega sistema. Preganjanje katoličanov na Ruskem, stanowiąca, jak głosi zamieszczony na odwrocie karty tytułowej dopisek, przyczynek do zrozumienia stosunków polsko-rosyjskich ${ }^{44}$. We wstępie autor podkreślał wagę tego posunięcia, które posiadać będzie ważne następstwa i powinno przyciągnąć uwagę światowej opinii publicznej. To tak, jakby, porównywał Lenard, w austriackiej Radzie Państwa dyskutowano nad projektem utworzenia z części różnych krajów, na przykład Styrii, Krainy i Karyntii, nowego kraju. Wspomniany projekt wyodrębnienia Chełmszczyzny rozpatrywał autor niejako z trzech punktów widzenia: ze stanowiska wiary, stanowiska słowiańskiego, wreszcie z ogólnoludzkiego i w każdym wypadku nazywał to gwałtem. Podkreślał, że konflikt pomiędzy dwoma największymi słowiańskimi narodami jest owym „martwym punktem”, który uniemożliwia postęp w sprawie słowiańskiej. Zwracał przy tym uwagę na fakt, że projekt rządu rosyjskiego stanowił bolesny cios dla Polaków i godził w nich bardziej niż niesławne akcje ich wywłaszczania w zaborze pruskim ${ }^{45}$. Przyczynę takiego stanu rzeczy widział Lenard w istniejącym systemie rządów w Rosji - samodzierżawiu i cezaropapizmie - niesprawiedliwym i szkodliwym zarówno dla państwa, jak i społeczeństwa. System ten, przekonywał Lenard, jest w istocie fikcją, gdyż naprawdę „Rosją rządzi biurokracja i ochrana”. Wstęp kończyła ogólna uwaga brzmiąca dla słoweńskiego czytelnika nieomal jak życzenie i postulat:

Samodzierżawie jest w Rosji źródłem wszelkiego zła i tak ogólnie z ludzkiego punktu widzenia i z miłości do bliźniego musimy życzyć sobie, aby wreszcie upadł w Rosji ten ustrój polityczny i żeby u naszych północnych słowiańskich braci zapanowała obywatelska i wyznaniowa wolnośśc ${ }^{46}$.

Broszura jest podzielona na cztery części: 1. Rys historyczny Podlasia i Ziemi Chełmskiej; 2. W jaki sposób ludność Chełmszczyzny przeszła na prawosławie; 3. Dekanat Konstantynowski, 4. Jak jest dzisiaj? Lenard, jak słusznie zauważył „Świat Słowiański”, ograniczył się do przedstawienia samych faktów, unikając polemicznych wywodów skierowanych przeciwko Rosji. Poruszające są jednak opisy autora w części drugiej, w której kreślił obraz przymusowego nawracania i podawał przykłady oporu ze strony „uporników”. Lenard, pisząc swoją broszurę, sięgnął nie tylko do źródeł pisanych i statystyk, ale, co z uznaniem podkreślał recenzent „Świata Słowiańskiego", oparł się na licznych rozmowach z dawnymi unitami i wygnanymi duchownymi.

Przechodząc do stanu bieżącego, Lenard przytaczał rządowe dane statystyczne dotyczące ludności nowo utworzonej guberni i czynił porównanie z liczbą ludności Krainy i Karyntii, liczącej mniej więcej tyle samo mieszkańców. Z danych

44 Idem, Krvav list iz zgodovine ruskega sistema. Prganjanje katoličanov na Ruskem, Ljubljana 1912; Dr. Leopold Lenard: Krvav list iz zgodovine ruskego sistema. Preganjanje katoličanov na Ruskem (Krwawa karta z dziejów systemu rosyjskiego. Prześladowanie katolików w Rosyi). Založilo „Društvo prijateliv poljskega naroda” v Ljubljani (nakładem ,, Towarzystwa Przyjaciót narodu polskiego w Lublanie”). Lublana (1912) [recenzja], „Świat Słowiański”, R. 8, t. 1, 1912, s. 292-293.

45 L. Lenard, Krvav list..., s. 3-5.

46 Ibidem, s. 6. Por. Dr. Leopold Lenard: Krvav list... [recenzja], s. 292. 
oficjalnych wynika, że prawosławni pozostają pomimo tego w mniejszości, a dane te i tak należałoby, zdaniem Lenarda, poprawić, biurokracja rosyjska bowiem w perfidny sposób do ludności prawosławnej wliczała również żołnierzy i urzędników, którzy przebywali na obszarze nowej guberni tylko tymczasowo ${ }^{47}$. Szczególnie przekonywające dla słoweńskiego czytelnika jest zestawienie przez Lenarda statystyk urzędowych i ksiąg parafialnych, z którego wynika, że według pierwszych istniałoby 40 gmin z większością prawosławną, a według drugich tylko 19, a w rzeczywistości jeszcze mniej ${ }^{48}$.

W zakończeniu Lenard zwracał uwagę na ogromne koszty, jakie pociągnie za sobą sztuczne tworzenie nowej guberni, a przede wszystkim na wielkie niezadowolenie ludności, którego wielkości nie sposób osądzić. Lenard w istocie starał się, jak to określił recenzent publikujący dla „Świata Słowiańskiego”, pisać rzeczowo, nie narzucać czytelnikowi żadnych opinii, ale przez to tym bardziej miał na niego oddziaływać, bo „fakty nie tylko mówią [...], ale krzyczą" "49. Ostatnie zdanie broszury nie pozostawiało jednak wątpliwości, jaka jest opinia Lenarda: „A jakże się stara władza o to, aby byłych «opornych», którzy odważyli się otwarcie przejść na katolicyzm, z pomocą więzien, konfiskat i nahajki ponownie włączyć do swojego prawosławia"50. Broszura Lenarda została jednoznacznie określona przez „Świat Słowiański” jako „przysługa (nie pierwsza), jaką nam wyświadcza zacny kapłan słowieński”.

Co do charakteru i funkcjonowania rosyjskiego systemu państwowego po reformie z lat 1906-1907, Lenard nie miał złudzeń. Nazwał go „wytworem najwyższego sprytu biurokracji rosyjskiej”, która uczyniła wszystko, aby „pod nowymi nazwami wszystko pozostało po staremu". Jako przykład posłużyła mu działalność cenzury rosyjskiej, z którą przyszło mu się zetknąć osobiście w czasie dłuższego pobytu w Warszawie pod koniec 1907 r. Swoje perypetie opisał w artykule opublikowanym najpierw w czasopiśmie „Slovenec”, a następnie zamieszczonym również w „Świecie Słowiańskim" pt. Z cenzury rosyjskiej (własne doświadczenie z niedawnego czasu) ${ }^{51}$. Opisał w nim na początku przypadek potraktowania przez cenzurę rosyjską stypendysty rządu austriackiego, późniejszego wybitnego słoweńskiego historyka i historyka literatury Ivana Prijatelja, a następnie swoją historię, kiedy zarekwirowano mu między innymi egzemplarze „Świata Słowiańskiego” i czeskiego „Slovanského Přehledu", książkę Mariana Zdziechowskiego Die Grundprobleme Russlands, dzieła Adama Mickiewicza i Henryka Sienkiewicza oraz broszurę socjalistyczną. Cenzor miał przy tym powtarzać: „Jakie liche Pan ma książki, jakie liche”, co oburzyło Lenarda i czemu dał otwarcie wyraz. Sprawa zakończyła się ostatecznie pomyślnie i po kilku tygodniach Lenardowi zwrócono wszystkie skonfiskowane książki ${ }^{52}$.

47 L. Lenard, Krvav list..., s. 60-65.

48 L. Lenard, Krvav list..., s. 66-67; Dr. Leopold Lenard: Krvav list... [recenzja], s. 293.

49 Dr. Leopold Lenard: Krvav list... [recenzja], s. 293.

50 L. Lenard, Krvav list..., s. 68.

51 [L. Lenard], Z cenzury rosyjskiej (własne doświadczenia z niedawnego czasu), „Świat Słowiański”, R. 4, t. 2, 1908, s. 1037-1042.

52 Ibidem, s. 1040-1042. 


\section{STOSUNKI POLSKO-UKRAIŃSKIE}

Obok zagadnienia dotyczącego idei słowiańskiej i związanych z nim stosunków polsko-rosyjskich uwaga Lenarda skupiała się również wokół stosunków polsko-ukraińskich. U źródeł, sięgającego jeszcze połowy XIX wieku, zainteresowania Słoweńców kwestią ukraińską leżał fakt, że Ukraińcy (wówczas nazywani Rusinami) należeli, podobnie jak Słoweńcy do tak zwanych narodów niehistorycznych, a niektóre z ich żądań narodowych pokrywały się z hasłami słoweńskiego odrodzenia narodowego. Sympatie proukraińskie wśród działaczy słoweńskich wynikały więc po części z istniejących podobieństw, gdy chodzi o sytuację polityczną i problem narodowościowy ${ }^{53}$. Dla słoweńskich działaczy, zarówno tych z drugiej połowy XIX wieku, jak i dla Lenarda, nie ulegało wątpliwości, że antagonizm polsko-ukraiński bywał podsycany w odpowiednim momencie i wykorzystywany dla własnych celów przez rząd i stronnictwo centralistów niemieckich, postępujących według zasady divide et impera. Spór polsko-ukraiński w Galicji, osłabiający jedność i siłę obozu federalistycznego, stanowił wcześniej przedmiot troski stronnictwa, tak zwanych starosłoweńców, a później wszystkich, którym bliska była idea wzajemności słowiańskiej ${ }^{54}$. Nie dziwi więc fakt, że nie mógł on być obojętny dla Lenarda.

Poświęcił mu broszurę pt. Die Wiener Tripel-Allianz und die Lemberger ,, Staatsund Hauptaktion, wydanej w roku 1907 w Wiedniu ${ }^{55}$. Tłem, a zarazem inspiracją do jej napisania, stał się ostry spór polsko-ukraiński, który wybuchł w związku z kampanią na rzecz utworzenia uniwersytetu ukraińskiego we Lwowie. Lenard postawił sobie za zadanie przedstawienie sytuacji w Galicji, głównie pod kątem kwestii narodowościowej, zwłaszcza gdy chodzi o szkolnictwo. Jednocześnie Lenard pragnął ukazać jednostronny atak prasy wiedeńskiej na Polaków, którym zarzucano nierespektowanie zasady równouprawnienia językowego. Tytuły trzech gazet wiedeńskich: „Arbeiter Zeitung”, „Neue Freie Presse” i „Deutsche Volksblatt” posłużyły mu do stworzenia sarkastycznie brzmiącego tytułu broszury. Obiektywizm sądów Lenarda i obnażenie owego sojuszu sił ukraińskich i prasy wiedeńskiej o obliczu socjalistycznym i nacjonalistycznym jest tym bardziej znamienne, że, jak sam zresztą wspominał we wstępie, poznał Ukraińców i ich język wcześniej niż Polaków, i chociaż poczuwał się do pokrewieństwa z oboma narodami, to biorąc pod uwagę tradycję i stosunki panujące w jego rodzinnym kraju, bliżej mu było do Ukraińców. Fakt przynależności

53 A. Cetnarowicz, Stoweński ruch narodowy i jego stosunek do spraw polskich (1848-1879), Kraków 1990, s. 30-31; idem, Polacy i Stoweńcy w monarchii habsburskiej. Uwagi na temat wzajemnych stosunków w drugiej połowie XIX wieku, „Prace Historyczne” 1997, nr 121: Austria - Polska, 1000 lat sąsiedztwa, red. J. Buszko, W. Leitsch, s. 216, 218.

54 Ibidem, s. 126-129; A. Cetnarowicz, Die polnisch-slowenischen Beziehungen aus der Sicht der slawischen Idee [w:] Entwicklung der Nationalbewegungen in Europa 1850-1914, hrsg. von H. Timmermann, Berlin 1998, s. 215, 219-220; idem, Stosunki polsko-ukraińskie i polsko-rosyjskie w opinii słoweńskiej w II połowie XIX wieku, „Acta Historica Neosoliensia, Vedecký časopis pre historicke vedý" 2015, t. 18, s. 161-179.

55 L. Lenard, Die Wiener „, Tripel-Allianz und die Lemberger Staats- und Hauptaktion”, Wien 1907. 
do akademickiego stowarzyszenia Akademiczna Hromada umacniał jak gdyby to stanowisko.

Okoliczności te dostrzegł Feliks Koneczny w recenzji broszury Lenarda, która ukazała się w „Świecie Słowiańskim” pt. Słoweński głos o stosunkach rusko-polskich $^{56}$. Lenard, według Konecznego, ukazał w swojej broszurze naiwność Ukraińców, którzy nie dostrzegli w poparciu ze strony prasy wiedeńskiej manewru politycznego. Zasługę Lenarda w przedstawieniu rzeczywistej sytuacji w Galicji, ale również we wskazaniu sposobów położenia kresu polsko-ukraińskiemu sporowi, podkreślał lublański recenzent broszury Evgen Lampe na łamach „Domu in sveta”. Ogólna konkluzja Lenarda była taka, że przeciwieństwa pomiędzy Polakami a Ukraińcami w Galicji nie są tak duże jak na przykład pomiędzy Czechami a Niemcami, lub Słoweńcami i Niemcami - właściwie, jak pisał, w teorii ich nie ma i gdyby nie wpływy obce, porozumienie byłoby możliwe ${ }^{57}$.

Przechodząc do meritum, Lenard przedstawiał sytuację w szkolnictwie ludowym w Galicji i postulat Ukraińców odnośnie do zwiększenia liczby szkół z językiem ukraińskim. Lenard dowodził, że szkół ukraińskich jest nominalnie więcej niż polskich i zarzucał Ukraińcom inercję, gdy chodzi o współpracę z władzami krajowymi i brak inicjatywy w tworzeniu na przykład czytelni ludowych. Wskazywał na ogólne przyczyny trudności w rozwoju kultury i oświaty, które wynikają z sytuacji ekonomicznej w Galicji, mającej swoje źródło po części w naturalnych warunkach, ale także z winy „wcześniejszych austriackich centralistycznych rządów”58.

Omawiając sytuację szkolnictwa średniego i postulat Ukraińców odnośnie do posiadania własnych gimnazjów, Lenard stwierdzał na wstępie, że co do tego panuje zasadniczo między Ukraińcami i Polakami zgoda. Nikt z Polaków, podkreślał, nie odmawia Ukraińcom tego prawa, o czym może świadczyć fakt, że otrzymali oni swoje gimnazjum skutkiem petycji sejmu galicyjskiego, do której przyłączyły się wszystkie polskie stronnictwa. Lenard czynił porównanie z sytuacją Słoweńców w Styrii i zadawał pytanie: „Czy można sobie wyobrazić podobną sytuację w sejmie styryjskim, w którym oto jednomyślnie zapada uchwała wszystkich posłów, domagająca się utworzenia słoweńskiego gimnazjum w Celju?”. Ukraińcy, stwierdzał Lenard, mają pięć gimnazjów, co wprawdzie, jak na liczącą trzy miliony ludności społeczność ukraińską, jest mało, jednak w porównaniu ze Słoweńcami, którzy nie posiadają ani jednego, ich los jest godny pozazdroszczenia. A trzeba jeszcze mieć na uwadze to, dodaje, że poziom kultury wśród Słoweńców jest o wiele wyższy niż Ukraińców. Sytuacja Słoweńców w Karyntii jest jeszcze o wiele gorsza, nie posiadają oni bowiem ani jednej szkoły ludowej, pomimo iż stanowią jedną trzecią liczby mieszkańców kraju ${ }^{59}$. Zasadniczo jednak w sprawie szkół średnich panuje pomiędzy

56 [F. Koneczny], Stoweński głos o stosunkach rusko-polskich, „Świat Słowiański”, R. 3, t. 2, 1907, s. 23-24.

57 L. Lenard, Die Wiener Tripel-Allianz..., s. 10; [F. Koneczny], op. cit., s. 25; [E. Lampe], Die Wiener ,, Tripel-Allianz" und die Lamberger ,, Staats- und Hauptaktion”, beleuchtet von Leopold Lenard. Wien 1907 [recenzja], „Dom in svet”, R. 20, 1907, nr 8, s. 379.

58 L. Lenard, Die Wiener Tripel-Allianz..., s. 12-15; [F. Koneczny], op. cit., s. 25-27.

59 L. Lenard, Die Wiener Tripel-Allianz..., s. 27-28; [F. Koneczny], op. cit., s. 27. 
Polakami i Ukraińcami pełne zrozumienie, stwierdzał Lenard, a różnice ujawniają się dopiero w praktyce, gdy rozważa się konkretny przypadek, czy istnieją warunki do założenia średniej szkoły ukraińskiej, czy nie. Lenard wytykał też Ukraińcom pewien nieład i brak organizacji, gdy chodzi o szkoły średnie, którym brakuje kadr nauczycielskich, a wielu spośród profesorów gimnazjów ukraińskich woli wybrać posady w szkołach polskich. Kończył jednak ten wątek optymistyczną uwagą, że spór Polaków i Ukraińców o szkoły średnie jest o wiele łagodniejszy niż pomiędzy Niemcami a Czechami czy Niemcami a Słoweńcami, ponieważ w Galicji panuje zgodność co do kwestii zasadniczej, podczas gdy z Niemcami walczy się o zasady ${ }^{60}$.

W końcu przechodzi Lenard do sprawy wywołującej w tym czasie największe kontrowersje, to jest do walki Ukraińców o własny uniwersytet we Lwowie, co przyrównywał do „dostania się w krzyżowy ogień artylerii”. Hasłu posiadania przez Ukraińców własnego uniwersytetu przeciwstawiają bowiem Polacy swoje, domagając się polskiego uniwersytetu. W dążeniu do osiągnięcia swojego celu Ukraińcy obrali, zdaniem Lenarda, złą taktykę, co należy tłumaczyć brakiem politycznej rutyny. Istnienie polskiego uniwersytetu we Lwowie mogłoby Ukraińcom ułatwić osiągnięcie swojego celu, ,gdyby nie trzymali się zgubnego zapatrywania, że należy najpierw wszystko zniszczyć, chcąc coś uzyskać”. Lenard wytykał politykom ukraińskim krótkowzroczność i niedostrzeganie w całej tej sprawie interesów niemieckich, wykorzystujących umiejętnie spór polsko-ukraiński ${ }^{61}$. Lansowany ostatnio przez „Neue Freie Presse” sojusz ukraińsko-niemiecki niczego im nie przyniesie, a jedynie usztywni postępowanie Polaków. Co do stanowiska Słowian południowych, Lenard wychodził z założenia, że każdy nowy słowiański uniwersytet w Austrii wzmacnia słowiański element w stosunku do Niemców. Można by się więc spodziewać, że w Radzie Państwa Słoweńcy mogliby do żądania Ukraińców dołączyć postulat słoweńskiego uniwersytetu w Lublanie", ale, jak przypuszczał Lenard, raczej zadowoliliby się na jakiś czas gruntownym przekształceniem uniwersytetu zagrzebskiego, dającego im możliwość ukończenia tam swoich studiów. Podsumowując zagadnienie uniwersytetu, Lenard stwierdzał, że z punktu widzenia Słowian szanse na realizację tego postulatu wyglądają dobrze, przeszkodę widział natomiast w mentalności ukraińskich przywódców, którzy nie potrafią wykorzystać tej dogodnej sytuacji politycznej ${ }^{62}$.

Osobny rozdział poświęcił Lenard rysowi charakterologicznemu i psychologii Ukraińców. Wskazywał na znamienną cechę, a mianowicie „zamiłowanie do wyrzekania", fatalizm, podejrzliwość zwłaszcza w stosunku do urzędników. Według Lenarda Ukraińcy nie rozumieją zasad konstytucjonalizmu, chcą nad sobą władzy „wprawdzie dobrej, patriarchalnej, ale też absolutystycznej, wszechwładnej”. Ten rys zbliża ich, zdaniem Lenarda, do Rosjan. Lenard, przedstawiając sytuację Ukraińców w oświacie, odwoływał się po raz kolejny do jej porównania z sytuacją Słoweńców.

\footnotetext{
60 L. Lenard, Die Wiener Tripel-Allianz..., s. 28-30; [F. Koneczny], op. cit., s. 28-29.

61 L. Lenard, Die Wiener Tripel-Allianz..., s. 35; [F. Koneczny], op. cit., s. 30.

62 L. Lenard, Die Wiener Tripel-Allianz..., s. 37.
} 
Ukraińcy mają, pisał, ukraińskie katedry w uniwersytecie, ,jakkolwiek co do poziomu kulturalnego i liczby słuchaczy stoją niżej od Słowieńców”63.

Lenard dowodził w podsumowaniu, że trudność porozumienia Polaków z Ukraińcami nie polega na przeciwieństwach teoretycznych, których, powtarzał, właściwie nie ma, lecz ujawniają się one dopiero w praktycznym działaniu, gdyż w jego tle pozostaje dążenie do „Eine freie Republik Ukrainien, ohne Popen und Herren” ${ }^{4}$.

W rozdziale VI Lenard podkreślał dobitnie, że sprzeczności pomiędzy Polakami a Ukraińcami nie mają charakteru sprzeczności narodowościowych, lecz noszą cechy konfliktów gospodarczych i społecznych, a te drugie kierują się nie przeciw narodowi polskiemu, lecz przeciwko ,gospodarce szlacheckiej”65.

W uwagach końcowych Lenard podsuwał warunki wstępne, które należałoby spełnić, aby przynajmniej ograniczyć spór polsko-ukraiński:

1. Należałoby starać się usunąć wszelki obcy wpływ na stosunki galicyjskie. Gdyby Ukraińcy zdani byli wyłącznie na własne siły, radykalizm utraciłby między nimi wszelki grunt. Należałoby wreszcie wyeliminować nacjonalizm niemiecki. 2. Do zakończenia sporu polsko-ukraińskiego i w ogóle waśni narodowościowych w Austrii przyczyniłoby się powstanie wśród Niemców austriackich prawdziwego stronnictwa państwowego [„,eine wirkliche Reichspartei"], które w przeciwieństwie do niemieckich nacjonalistów obrałoby za cel ochronę austriackich interesów państwowych i utrzymanie cesarstwa ${ }^{66}$.

Feliks Koneczny wystawiał broszurze Lenarda wysoką ocenę. Podkreślał, że autor traktował każdą kwestię na szerszym tle, że nie jest politykiem „na wyrywki”, ale umysłem prawdziwie politycznym, rozumiejącym związek spraw i wzajemną ich od siebie zależność". Broszurę tę powinni, zdaniem Konecznego, powitać z uznaniem Polacy, Ukraińcy i „wszyscy ludzie dobrej woli”. Redaktor naczelny „Świata Słowiańskiego" przyjmował krytykę Lenarda wobec Polaków ze zrozumieniem. Nie powinno to być, stwierdzał, powodem do obrażania się, lecz widząc dobrą wolę autora, dostrzegał w nim ,tem lepszego, tem pewniejszego przyjaciela, że się nie zniża do pochlebstw". Lenard jest, według Konecznego, również dobrym przyjacielem Ukraińców, a jego głos ma jedynie Polakom i Ukraińcom dopomóc do porozumienia. Dojście do takiego porozumienia uzależniał Koneczny od tego, „,zy są tacy Rusini, którzy porozumienia pragną". Gdyby tacy istotnie się znaleźli, to wtedy, według Konecznego, „mogłaby broszura X. Lenarda oddać walne usługi zwolennikom porozumienia. Posuwa bowiem dyskusję wstępną o znaczny krok naprzód, określając całą sprawę teoretycznie nader trafnie i osadzając ją na głębszych politycznych podstawach”. Na koniec zachęcał Koneczny wszystkich Ukraińców do wypowiadania się w sprawie broszury Lenarda i do podjęcia dyskusji ${ }^{67}$.

Słoweński recenzent broszury Lenarda Evgen Lampe dochodził do podobnych wniosków; dowodził, że między Polakami i Ukraińcami nie ma takich przeciwieństw,

63 Ibidem, s. 47-49; [F. Koneczny], op. cit., s. 31-32.

64 L. Lenard, Die Wiener Tripel-Allianz..., s. 51.

65 Ibidem, s. 52-56.

66 L. Lenard, Die Wiener Tripel-Allianz..., s. 60-63. Feliks Koneczny w swej recenzji przytacza uwagi końcowe w całości: [F. Koneczny], op. cit., s. 34-35.

${ }_{67}$ [F. Koneczny], op. cit., s. 35-36. 
które by uniemożliwiały znalezienie pokojowego, zadowalającego obie strony rozwiązania. Gdy mowa o szkolnictwie ludowym i gimnazjalnym, podzielał opinię Lenarda, że Polacy oddają Ukraińcom to, co się im prawnie należy, natomiast obie strony domagają się własnego uniwersytetu we Lwowie. Lampe stwierdza, że uniwersytet lwowski jest po wiedeńskim i praskim najbardziej uczęszczanym w Austrii i słusznie należy się Polakom. Przytaczał zdanie Lenarda, że do założenia ukraińskiego uniwersytetu we Lwowie istnieją sprzyjające okoliczności, a główną przeszkodę widział w błędnej taktyce Ukraińców, ponieważ ich przywódcy pozostają w sojuszu z Niemcami, irredentystami i socjalistami. Lenard, zdaniem Lampego, charakteryzuje na podstawie własnych obserwacji indolencję społeczeństwa ukraińskiego, ulegającego hasłom ,wolna socjalistyczna republika ukraińska bez popów i panów”. Społeczeństwo to, według Lampego, karmione frazesami, zamiast zając się pracą społeczną pozostaje niewykształcone i opuszczone. W ocenie Lampego Lenard broni polską szlachtę przed bezpodstawnymi oskarżeniami i podkreśla, jak wiele uczyniła dla Polski pod względem duchowym i materialnym. Lampe podzielał wiarę Lenarda w pomyślne rozwiązanie sporu, pod warunkiem że Ukraińcy porzucą opieranie się na wrogiej Słowianom partii i stworzą dający się zrealizować program narodowo-kulturalny. Na koniec zwracał uwagę, że polska prasa powitała broszurę Lenarda z sympatią ${ }^{68}$.

Lenard w czasie swoich studiów we Lwowie miał okazję poznać bliżej Ukraińców, ich język i kulturę nie tylko na obszarze Galicji Wschodniej, ale również zapuszczając się na Podole, do Besarabii czy na Bukowinę. Znał i thumaczył między innymi dzieła Iwana Kotlarewśkiego, Wasyla Stefanyka, czy Olhy Kobylanśkiej, którą poznał osobiście w Czerniowcach. W artykule pt. Kamjenec in Hotin zamieszczonym w „Domu in svecie” w roku 1907, opisał swoje wrażenia z podróży na dawne polskie kresy, znane mu dotąd tylko z trylogii Sienkiewicza, ilustrując ponadto tekst przez siebie wykonanymi fotografiami ${ }^{69}$. Innym razem opisał pełen przygód wieczór i noc spędzone na krótko przed Bożym Narodzeniem w Humaniu, gdzie znalazł się trochę przypadkiem, wybrawszy się z Warszawy (z paszportem wydanym na podstawie podrobionych dokumentów!) w odwiedziny do znajomego zamieszkującego Koziatyn. Był to czas wrzenia rewolucyjnego w Rosji. Lenard obawiał się, że jako „obcy” może zostać zadenuncjowany policji przez właściciela hotelu, dlatego postanowił udać się do miejscowego teatrzyku, gdzie za kulisami znalazł miłe towarzystwo aktorów, z którymi śpiewał ukraińskie pieśni. Pod koniec atmosfera stała się bardziej „bojowa”, gdy aktorzy, wydobywszy noże, zaśpiewali pieśni hajdamackie o antyrosyjskiej treści ${ }^{70}$.

Z Ukraińcami przyszło mu się spotkać całkiem nieoczekiwanie na początku I wojny światowej. Mowa o grupie przebywających w podlublańskim Šentvid

${ }^{68}$ [E. Lampe], op. cit.

69 L. Lenard, Kamjenec in Hotin. Potopisna črtica, „Dom in svet”, R. 20, 1907, nr 2, s. 67-71, 111-117, 156-159.

70 Idem, Sveti večer na Ukrajini, „Dom in svet”, R. 22, 1909, nr 1, s. 34-40, 78-83. W spuściźnie Lenarda przechowywanej w NUK znajduje się maszynopis tego opowiadania w języku serbskim (NUK, Ms. 1880, Jedna noć na Ukrajini (čudni doživljaj mladog Slovenca)). 
politycznych zesłańców, wśród których znajdował się reprezentujący moskalofilską orientację Myhajło Zubryćkyj. Zubryćkyj stosunkowo szybko nawiązał kontakty ze słoweńskimi działaczami kulturalnymi i publicystami. Interesował się żywo historią, etnologią i językiem słoweńskim, czytywał regularnie prasę słoweńską, między innymi „Slovenca”, „Dom in svet”. W swoim „Słoweńskim dzienniczku” odnotowywał spotkania z Lenardem, omawiał jego prace i poglądy dotyczące spraw galicyjskich, ukraińskich i ogólnosłowiańskich ${ }^{71}$. Cytował przy tym w oryginale wypiski z artykułów Lenarda opisujących trudną sytuację ekonomiczną w Galicji i wskazujących na jedyny sposób jej poprawy poprzez otwarcie się na handel z Rosją. Zubryćkyj wspominał między innymi o tym, że Lenard miał napisać w jednej z gazet polskich o planach Berlina wobec Ukrainy, osadzenia tam dynastii Hohenzollernów, a następnie kontynuowania ekspansji w kierunku Rumunii, Bułgarii i Albanii. Odnotowywał również sąd Lenarda odnośnie do polityki rządu austriackiego, który raz popierał Polaków, a innym razem Ukraińców ${ }^{72}$. Lenard miał się również włączać w dyskusję na tematy dotyczące języka i ortografii ukraińskiej, wypominając między innymi Ukraińcom usunięcie twardego znaku i sprzeniewierzenie się w ten sposób św. Metodemu i Cyrylowi. Zarzucał ponadto Ukraińcom, że w polityce postępują razem z Niemcami i przez to szkodzą Słowianom. Powoływał się przy tym na przykłady z Bukowiny, gdzie uderzały go wszędzie niemieckie napisy i mowa na ulicach. Dobre wrażenie wywarł natomiast Lenard na Ukraińcach, gdy deklamował ich wiersze i pieśni, między innymi Szcze ne wmerła Ukrajina. Zubryćkyj odnotowywał również ukazanie się broszury Lenarda Die Wiener Tripel-Allianz und die Lemberger Staatsund Hauptaktion. Podnosił przy tym zarzut Lenarda, mówiący o tym, że przywódcy ukraińscy liczą na cudzą pomoc, która jest wroga Słowianom. Podkreślał też sąd Lenarda, że Polacy okazali się sprawiedliwi wobec Ukraińców, dając im szkoły ludowe i gimnazja, jednak tylko uniwersytet we Lwowie chcą zatrzymać dla siebie. Nie pomijał również cytowanej już fanatycznej idei Ukraińców, streszczającej się w słowach: „Niezależna socjalistyczna republika ukraińska bez popów i panów”, a także trzymanie z irredentystami i socjalistami. Zubryćkyj kończył swoją krótką opinię o broszurze Lenarda jego uwagą, że polska szlachta zrobiła dużo więcej dla Polski ${ }^{73}$.

Poszukując różnych płaszczyzn, na których mogłaby się rozwijać idea słowiańska, Lenard jako duchowny nie pomijał również kwestii zjednoczenia Kościołów zachodniego i wschodniego. W zjednoczeniu obu Kościołów widział przede wszystkim problem polityczny, ale ostatecznie odrzucał go, dostrzegając zbyt głębokie różnice i sprzeczności. „Wszelka unia - pisał - byłaby nieudaną próbą powstałą dzięki działaniom politycznym i trwającą tak długo, jak długo byłaby przez te działania podtrzymywana" ${ }^{\text {"4 }}$.

71 М. Зубрицький, Зібрані твори і матеріали у трьох томах, т. 2: Матеріали до біографї, Львів 2016, s. 102-148.

72 Ibidem, s. 140-141.

73 Ibidem, s. 145-146.

${ }_{74}$ I. Gantar Godina, Dr. Leopold Lenard..., s. 398; M. Tominšek, op. cit., s. 620. 


\section{POLSKA I POLACY WZOREM DLA SŁOWEŃCÓW}

Lenard ubolewał nad stanem słoweńskiej inteligencji. Zarzucał jej, że jest nieliczna, mało aktywna i zbytnio pozostająca pod wpływem niemieckiej kultury. Za pilną i palącą potrzebę uważał więc wychowanie narodowej, zaangażowanej inteligencji, wolnej od demoralizującego i wynaradawiającego wpływu niemieckiej kultury. Odradzał w związku z tym słoweńskiej młodzieży podejmowanie studiów na niemieckich uniwersytetach, gdzie istnieją coraz gorsze warunki. W polu widzenia pozostawały zatem uniwersytety w Pradze, Krakowie i Lwowie. Lenard stwierdzał, że od lat wśród młodzieży słoweńskiej popularne są studia w Pradze, co uznawał zresztą za rzecz naturalną, zważywszy na żywe kontakty z Czechami, oparte na wrogości do Niemców, na wyznawaniu idei wzajemności słowiańskiej i wspólnych sympatiach do Rosji. Na podstawie własnych obserwacji i doświadczenia ze studiów we Lwowie i Krakowie oraz bogatej wiedzy dotyczącej historii i kultury polskiej, a także kontaktów z inteligencją polską, zachęcał jednak do podejmowania studiów w Krakowie, wyliczając różne tego zalety:

1. Kraków jest czysto słowiańskim miastem, a niemiecka kultura oddziałuje tu słabo i w sposób pośredni. Natomiast silne pozostają tu wpływy starych, światowych kultur Francji, Anglii i Włoch. 2. Wpływ słowiańskich, polskich tradycji oddziaływałby pozytywnie na rozwój ducha i myślenie słoweńskiej młodzieży. Kraków jest najbardziej słowiańskim miastem, gdzie na każdym kroku spotyka się pomniki sławnej przeszłości. 3. Kraków stanowi centrum politycznej myśli, gdzie szeroko rozwinęły się wszystkie teorie politycznego, wyznaniowego i gospodarczego konserwatyzmu, ,profesorskiego liberalizmu”, socjalizmu i nacjonalizmu. Odnaleźć tu można również ideę słowiańską, nie tylko w czasie spotkań, ale również w konkretnych programach. 4. Polacy mają najwięcej taktu i ogłady spośród wszystkich Słowian. W czasach swej największej potęgi pozostawali w bliskich kontaktach z najbardziej światłymi narodami świata. 5. Kraków jest miastem nauki i sztuki, jak chyba żadne inne miasto. Posiada znakomity uniwersytet z 4 tysiącami słuchaczy, prężnie działającą Akademię Umiejętności, prywatną szkołę na prawach uniwersytetu dla kobiet, cały szereg różnego rodzaju szkół średnich oraz towarzystw naukowych i artystycznych ${ }^{75}$.

Lenard był przekonany, że polskie społeczeństwo przyjęłoby dobrze słoweńskiego studenta, otwarłoby przed nim szeroko wszelkie wrota, a zatem, konkludował, studia w krakowskim uniwersytecie wywierałyby wielki wpływ na słoweńskie stosunki polityczne i narodowe ${ }^{76}$.

Koneczny podziękował Lenardowi i Słoweńcom za to stanowisko na łamach „Świata Słowiańskiego”. Uczynił to jednak w sposób szczególny, zamiast mile

75 L. Lenard, Naše gorje!, „Zora”, t. 13, 1907, s. 53-54.

76 Ibidem, s. 54; por. też: Z. Darasz, Polacy $i$ Stoweńcy we wzajemnych relacjach $w$ świetle publicystyki doby monarchii austro-węgierskiej [w:] W Galicji i nad Soča. Polacy i Stoweńcy na frontach I wojny światowej, red. A. Cetnarowicz, D. Nećak, S. Pijaj, B. Todorović, Kraków 2014, s. 43-44; V. Melik, P. Vodopivec, Slovenski izobraženci in avstrijske visoke šole 1858-1918, „Zgodovinski časopis”, t. 40, 1986, s. 269-282; I. Gantar Godina, Slovene students in Central and Eastern Europe up to 1918, „Dve domovini” 1996, nr 6, s. 251-253; I. Gantar Godina, L. Lenard..., s. 398; M. Tominšek, op. cit., s. 621-623. 
brzmiących słów i pochwał przekazał im zapewnienie o gotowości wspierania i udzielania rad, ,jakich użyć środków, żeby [...] z ziem słoweńskich zrobić jednolitą Słowenię i żeby Trójjedyne Królestwo nie było tylko frazesem do mów i toastów"77.

Lenard po powrocie do Lublany w roku 1908 włączył się do dyskusji na temat powołania do życia uniwersytetu słoweńskiego. W dyskusji tej uczestniczyli również inni Słoweńcy studiujący w Krakowie Josip Stuller i Vojeslav Mole. Stuller winił samych Słoweńców za to, że sprawa uniwersytetu w Lublanie nie postępuje naprzód. Odrzucał przy tym jako bezpodstawną słoweńską krytykę środowisk polskich, które jakoby były niezainteresowane tym problemem, i przytaczał przykłady świadczące o gorącym poparciu tej idei przez środowisko krakowskiego Klubu Słowiańskiego i czasopisma „Świat Słowiański” oraz pełne sympatii stanowisko młodzieży akademickiej Krakowa ${ }^{78}$.

Poruszając zagadnienie studiów Słoweńców na polskich uniwersytetach, Lenard kreślił szersze tło stosunków polsko-słoweńskich. Zwracał uwagę na fakt, że istotnie Słoweńcy mieli z Polakami, należącymi do tak zwanych narodów historycznych, słabe kontakty. Twierdził, że różniła ich też polityka; Słoweńcy zarzucali Polakom, że nie czują się Słowianami i są egoistami ${ }^{79}$. Polacy mieli spoglądać na Słoweńców spode łba jako na naród niehistoryczny, zarzucając im na dodatek moskalofilstwo, na co, według Lenarda, Słoweńcy, postępując lekkomyślnie, zasłużyli. Lenard starał się tłumaczyć politykę Polaków w Austrii, która w sumie służy interesom Słowian. Przypominał ich zasługi $\mathrm{w}$ dziele pokonania niemieckiego centralizmu oraz konsekwentne działania zapobiegające utrwaleniu się w Austrii niemieckich rządów. Przyznawał wreszcie, że Słoweńcy zbyt mało poznali i rozumieli politykę polską i zbyt surowo ją oceniali. To sprawiło, że kontakty polsko-słoweńskie pozostały wąskie, a studenci słoweńscy chętniej wybierali Pragę. Ale Praga, dowodził Lenard, nie wniosła do życia Słoweńców żadnych szczególnych myśli i idei, z wyjątkiem „Svobodnej misli” (liberalizmu) i ideologii Masaryka. Z całym przekonaniem twierdził, że dla społecznego rozwoju Słoweńców i ich kultury, a także politycznego myślenia, większe korzyści przyniosłoby im studiowanie na polskich uniwersytetach. Tam nauczyliby się tego, co określa się jako kulturę społeczną, a stara słowiańska kultura wpłynęłaby korzystnie na ich duchowy rozwój. Związki młodzieży słoweńskiej z polską miałyby również pozytywny wpływ na szerzenie wśród niej idealizmu, czego brakuje Słoweńcom. Polacy bowiem, zdaniem Lenarda, to naród entuzjastyczny, przepojony idealizmem do tego stopnia, że często skłonni są kierować się bardziej uczuciem niż rozumem. „Po upadku swojego państwa - pisał - nieudane próby odzyskania swej ojczyzny jeszcze bardziej uwydatniły tę stronę polskiego ducha”. „Naszej młodzieży - kończył swój wywód Lenard - z pewnością nie zaszkodziłyby bliższe kontakty z Polakami, podbudowałyby wśród nich idealizm, zaś Polakom

77 Zob. Z. Darasz, op. cit., s. 44-45.

78 J. Stuller, O stališču Poljakov in poljskega akademskega dijaštva do slovenskega vseučilišnega vprašanja, „Zora”, t. 12, 1907, s. 102-106; idem, Krakov in slovensko dijaštvo, „Zora”, t. 12, 1907, s. 179-185; idem, Dopis iz Krakova, „Zora”, t. 12, 1907, s. 114-115.

79 Zob. A. Cetnarowicz, Polacy i Stoweńcy..., s. 203-220. 
również nie zaszkodziłoby, gdyby [dzięki tym kontaktom] zaczęli bardziej trzeźwo spoglądać na życie" $"$.

Do zagadnienia stosunków polsko-słoweńskich i różnych towarzyszących im nieporozumień powrócił Lenard w opublikowanym rok później na łamach „Świata Słowiańskiego" artykule Czy Polacy czują się Słowianami ${ }^{81}$. Powracał w nim do stawianego przez Słoweńców zarzutu, że Polacy nie czują się Słowianami i nie współdziałają z nimi. Zarzut ten uważał jednak za całkowicie nieuzasadniony i bezpodstawny dla każdego, który chociaż trochę zapoznał się z historią Polski i jej literaturą. Słowianofilstwo jest bowiem, zdaniem Lenarda, ,czerwoną nicią przebiegającą przez całą historię Polski i całą polską literaturę". Znacznie wcześniej, zanim inni Słowianie zaczęli mówić i pisać o idei słowiańskiej, „Polacy już krew za nią przelewali”. „Państwo polskie - podkreślał Lenard - powstało w walce o ideę słowiańską i padło w boju o nią przeciw wpływowi niemieckiemu". Zastanawiał się, czy to raczej idea wszechsłowiańska nie jest spaczona, podczas gdy Polacy pozostali wierni tradycjom swych przodków, którzy przelewali za nią krew, walcząc pod Grunwaldem, pod Warną i pod Orszą ${ }^{82}$. W zachowaniu się Słowian wobec Polaków dostrzegał Lenard wiele nieszczerości, obłudy i krzywdzących sądów. Słowianie powinni otwarcie przyznać Polakom prawo do niepodległości, której pozbawiono ich gwałtem, i winni to uczynić ,ze stanowiska słowiańskiego”. Dla Słowiańszczyzny byłoby korzystniej, gdyby Polska odłączyła się zupełnie od Rosji. „Ruch słowiański - stwierdzał Lenard - żądał dotychczas od Polaków samych tylko ofiar, a nic im nie oferował. To się musi zmienić do gruntu, a wówczas może idea słowiańska przynieść doniosłe skutki"83. Poruszony najwyraźniej tym szczerym wyznaniem słoweńskiego polonofila Feliks Koneczny, autor streszczenia, napisał na końcu rozstrzelonym drukiem: „Tak śmiałego i szczerego głosu nie słyszeliśmy jeszcze w Słowiańszczyźnie"»4.

W rozwoju idei słowiańskiej na początku XX wieku wielkie znaczenie miały niewątpliwie obchody 500. rocznicy zwycięstwa pod Grunwaldem, które przypadły w lipcu 1910 roku. Dla Lenarda, tak mocno podkreślającego konieczność przeciwstawienia się Słowian naporowi niemieckiemu, wydarzenie to nabierało charakteru symbolicznego. Jeszcze rok przed tą rocznicą zamieścił na łamach „Slovenca” artykuł Bitka pod Grunwaldom, w którym streścił pokrótce historię konfliktu polsko-krzyżackiego, a następnie opisał samą bitwę. W zakończeniu podkreślił, że dzięki temu zwycięstwu została złamana potęga Krzyżaków, a tym samym odsunięte zostało na kilka stuleci niemieckie niebezpieczeństwo dla Europy północno-wschodniej ${ }^{85}$.

80 L. Lenard, Poljske visoke šole in Slovenci, „Zora”, t. 9-10, 1908-1909, s. 106-108; I. Gantar Godina, L. Lenard..., s. 398-399.

81 L. Lenard, Czy Polacy czują się Stowianami. Z prasy słoweńskiej, „Świat Słowiański”, R. 6, t. 2, 1910, nr 69-70, s. 193-195 (jest to streszczenie artykułu, który ukazał się w „Slovencu”, 17 IX 1910); Z. Darasz, op. cit., s. 43.

82 L. Lenard, Czy Polacy czują się Stowianami..., s. 194.

83 Ibidem, s. 195.

84 Ibidem, s. 195; Z. Darasz, op. cit., s. 43.

85 L. Lenard, Bitka pod Grunvaldom, „Slovenec”, R. 37, 30 X 1909. 
Rok później Lenard zjawił się w Krakowie, aby wziąć udział w obchodach rocznicy bitwy pod Grunwaldem. Jednocześnie, o czym była już mowa, złożył rygoroza doktorskie na Wydziale Filozoficznym Uniwersytetu Jagiellońskiego i 29 lipca 1910 roku odebrał dyplom doktorski. Obchody grunwaldzkie, które opisał obszernie na łamach „Domu in sveta" ${ }^{86}$, stały się dla niego okazją do poruszenia zagadnienia idei słowiańskiej, połączonej z wiarą $\mathrm{w}$ przebudzenie się ducha narodowego i ludowego. Na wstępie podkreślił znaczenie bitwy w powstrzymaniu niemieckiego parcia na wschód, a także dla narodzin polskiej idei jagiellońskiej i mesjanizmu. Wskazał na ogólną sytuację, w jakiej przychodzi obecnie Polakom świętować rocznicę bitwy pod Grunwaldem - na germanizację, wywłaszczenia w zaborze pruskim oraz rusyfikację, nieład w administracji i zacofanie gospodarcze w zaborze rosyjskim. Dosyć powściągliwej postawie konserwatystów krakowskich co do charakteru obchodów Lenard przeciwstawiał „,przebudzenie się na ziemiach polskich ducha ludowego" z niejasnym wprawdzie jeszcze programem, ale odznaczające się wielkim rozmachem. Obchody rocznicy bitwy pod Grunwaldem stawały się, według Lenarda, właśnie jednym z przejawów budzenia się „,ducha polskiego ludu”. „Tak jak bitwa pod Grunwaldem - pisal - stanowiła początek polskiej chwały, tak pięćsetna rocznica tego zwycięstwa jest początkiem świadomości naszego chłopa i robotnika"87. W barwnym opisie uroczystości odsłonięcia pomnika grunwaldzkiego nie pominął Lenard pewnego szczegółu, który nawiązywał do głoszonej przez niego idei wzajemności słowiańskiej. Wspomniał mianowicie o obecności i przemówieniach gości z Rosji prof. Michaiła Pogodina i Fiodora Rodiczewa, posła do Dumy, który miał wielokrotnie oskarżać rząd o ucisk wobec Polaków. Oba przemówienia zakończone okrzykami „Niech żyje Polska!” zostały dobrze przyjęte przez zebranych. W swoją barwną relację z uroczystości wplatał Lenard myśli, które z całą pewnością towarzyszyły mu w czasie ich trwania, a dotyczyły idei wzajemności słowiańskiej. Dotykając stosunków polsko-rosyjskich, Lenard podkreślał, że:

[...] trudno jest wymagać, aby idea wzajemności słowiańskiej przeniknęła do polskiej duszy, gdy brak jej podstaw zarówno w historii, jak i w obecnym położeniu polskiego narodu. Trzeba najpierw stworzyć warunki, aby wzajemność słowiańska stała się dla Polaków praktyczną potrzebą, albo żeby im obiecała realne korzyści [...] tego nie mógł im zaoferować obecny moskalofilski kształt wzajemności słowiańskiej. [...]

Ruch słowiański rozwijał się w takich ramach, że Polacy w żaden sposób nie mogli się do niego przyłączyćc 8 .

Lenard był pod silnym wrażeniem barwnego pochodu, który z Błoń krakowskich podążał na Wawel. Urzekły go stroje i postawa chłopstwa. „Polski chłop nie jest już - pisał - tym kim był przed laty. W krótkim czasie dokonała się w Galicji rewolucja w pojęciach i poglądach chłopstwa [...]. Z grobów powstaje nowa, młoda Polska,

86 Idem, Grunvaldske slavnosti v Krakovu, „Dom in svet”, R. 23, 1910, nr 10, s. 454-458, 499-502.

87 Ibidem, s. 454-455.

88 Ibidem, s. 499. 
w sercu wrze i kipi, tylko brak im jasno wytkniętej drogi i przewodnika"89. Widać wyraźnie, że nieobca była Lenardowi ideologia młodopolska i ludomania.

W czasie swoich pobytów w Polsce, a także na podstawie bogatych kontaktów z historykami, slawistami i językoznawcami, Lenard miał okazję przekonać się, jak niewiele jest w języku polskim prac przybliżających Polakom dzieje Słoweńców, ich kulturę i język. W roku 1913 zdecydował się opublikować w Warszawie w ramach „Prac Filologicznych” rozprawę pt. Rozwój historyczny gramatyki słoweńskiej, będącą właściwie tylko wstępem i pierwszym rozdziałem większego dzieła. Przez słoweńskie środowisko naukowe w osobie Borisa Kidriča praca ta została w sposób dość jednostronny mocno skrytykowana. Barbara Oczkowa dostrzega jednak niezaprzeczalne jej wartości, wśród których wymienia sam pomysł jej napisania, a ponadto przedstawienie bogatego materiału bibliograficzno-faktograficznego i językowego, a ,wszystko na tle historyczno-kulturalnych zdarzeń epoki" ${ }^{90}$. Być może to właśnie ta praca miała stanowić podstawę habilitacji na Uniwersytecie Jagiellońskim, ostatecznie zablokowanej przez Mariana Zdziechowskiego, którą ten, według słów Vojeslawa Molégo, uznał za „niedojrzałą i nieinteligentną" ${ }^{\text {91 }}$. Recenzent pracy podkreślał na łamach „Domu in sveta” jej walory, przede wszystkim ukazanie rozwoju języka słoweńskiego poprzez historię gramatyki. Stwierdzał wprawdzie, że czytelnik nie znajdzie w niej niczego nowego, ale zwracał przy tym uwagę, że była to dopiero połowa zamierzonej pracy ${ }^{92}$.

Przykłady fascynacji Lenarda dziejami i kulturą polską odnaleźć można przede wszystkim w jego działalności publicystycznej. Dzięki jego artykułom, a niekiedy tylko krótkim informacjom zamieszczanym w rubryce Kronika na łamach czasopism „Dom in svet”, „Čas” i innych, mógł czytelnik słoweński zapoznać się z dziejami, kulturą i sławnymi postaciami polskimi. Wielką rolę odegrały tu przekłady dzieł autorów polskich, przede wszystkim Henryka Sienkiewicza. W roku 1912 w kolejnych numerach „Slovenca” ukazywało się w odcinkach tłumaczenie cieszącego się ogromną popularnością dzieła Sienkiewicza W pustyni i w puszczy [V pustinji in puščavi $]^{93}$. Po śmierci Sienkiewicza w roku 1916 ukazał się na łamach „Domu in sveta” obszerny artykuł pióra Lenarda, prezentujący sylwetkę i twórczość polskiego pisarza ${ }^{94}$. Lenard nazwał Sienkiewicza pisarzem i prorokiem polskiej idei narodowej, zmarłym

89 Ibidem, s. 501.

90 B. Oczkowa, op. cit., s. 295-303.

91 V. Molé, op. cit., s. 64-65; B. Oczkowa, op. cit., s. 295; M. Tominšek, op. cit., s. 613. Wszystko wskazuje na to, że Lenard i Molé za sobą nie przepadali, bo trudno uwierzyć, żeby przebywając w tym samym czasie w Krakowie, nie spotkali się. Lenard w ogóle nie wspomina nic o Molém, a ten drugi, obok informacji przekazanej Zdziechowskiemu, że Lenard został wysłany do Krakowa przez kręgi katolickie, podaje właśnie tylko tę o surowej ocenie jego habilitacji.

92 J. Šilc, Dr. Leopold Lenard, Rozwój historyczny gramatyki słoweńskiej [recenzja], „Dom in svet", R. 26, 1913, nr 6, s. 236.

93 Jeszcze w okresie międzywojennym wydawnictwo Jugoslovanska knjigarna w Lublanie zwracało się do Lenarda z zapytaniem o zgodę i warunki dotyczące opublikowania przekładu tego dzieła, a także innych prac Sienkiewicza (NUK, Ms. 1880, Korespondencija, Jugoslovanska knjigarna do L. Lenarda, 25 II 1930).

94 L. Lenard, Henryk Sienkiewicz, „Dom in svet”, R. 30, 1917, nr 1/2, s. 67-69. 
dokładnie w czasie, gdy Polska powstawała z grobu. Według Lenarda w twórczości Sienkiewicza nicią przewodnią była polska myśl państwowa, przedstawiona najpełniej w Trylogii. Myśl tę pragnął spopularyzować w polskim społeczeństwie - i to mu się w pełni powiodło. Lenard z twórczości Sienkiewicza umiejętnie wydobywał istotne cechy Polaków. Jako przykład posłużyła mu postać króla Jana III Sobieskiego i podjęta przez niego wyprawa wiedeńska, przedstawiona w powieści Na polu chwaty. Zdaniem Lenarda Polak jest idealistą i dla realizacji idealistycznych celów gotów jest poświęcić swoje własne korzyści. W pustyni $i$ w puszczy określał Lenard jako jedną z najlepszych powieści pośród tych, których celem jest „obudzić wśród młodzieży rycerskiego i żołnierskiego ducha i wpajać jej program narodowy". W zakończeniu artykułu Lenard powracał w myślach do spotkania z domem Sienkiewiczów w Warszawie i zainteresowania, jakie wielki pisarz okazywał wobec Słoweńców i ich sytuacji ${ }^{95}$.

Za sprawą Lenarda, a także innego Słoweńca, Francè’a Stelègo na łamach „Domu in sveta" pojawiały się regularnie artykuły, czasem tylko krótkie doniesienia, przybliżające polskich uczonych i pisarzy oraz ważniejsze wydarzenia z Polski. Na przykład w roku 1907 pojawiła się krótka notatka, ale pod znaczącym tytułem Spominek poljske slave, w którym Lenard pisał o niszczejącym w dalekiej Besarabii pomniku hetmana Stanisława Żółkiewskiego, zwycięzcy spod Cecory w roku 1620. Chwalił inicjatywę Rosjanina niejakiego Butowicza, podejmującego się odnowy pomnika „wielkiego bohatera polskiego" ${ }^{\text {. }}$. W tym samym numerze donosił o śmierci Katarzyny z Branickich Potockiej, żony Adama Potockiego, podkreślając rolę obojga w czasie rewolucji krakowskiej w 1846 roku i podczas wypadków roku 1848 w Krakowie, oraz o śmierci pisarza Feliksa Kozubowskiego ${ }^{97}$. W rubryce Poljska „Dom in svet" z roku 1907 opublikował krótki artykuł Lenarda przypominający początki prasy i poczty polskiej, sięgające XVI wieku. Autor podkreślił późniejsze zasługi na tym polu jezuitów, ukazanie się „Kurjera Polskiego” i „Gazety Warszawskiej”. Zauważył także stały wzrost czasopiśmiennictwa polskiego na Ślą̨ku Cieszyńskim, co miało świadczyć o budzeniu się tam świadomości narodowej. Wspominał również o wydawaniu w Cieszynie przez Władysława Zabawskiego „Dziennika Cieszyńskiego", adresowanego do szerokich warstw ${ }^{98}$. W roku $1900 \mathrm{w}$ tej samej rubryce pojawiła się informacja Lenarda o ukazaniu się czwartego tomu zbioru nowel Kazimierza Przerwy-Tetmajera Na skalnem Podhalu. Dzieło to stanowiło, według niego, wyraźną tendencję, że kultura zwraca się ku ludowi. Zdaniem Lenarda Polacy, którzy najbardziej spośród wszystkich Słowian przejmowali kulturę Zachodu, spostrzegli, że to nie wystarczy i że należy sięgać do kultury ludowej ${ }^{99}$. W tym samym roku

95 Ibidem, s. 69. O związkach Lenarda z Sienkiewiczem i o tym, że był zapraszany przez niego w Warszawie na herbatę, wspomina po latach żona Lenarda w korespondencji z Vekoslawem Bučarem (V. Bučar, op. cit., s. 77).

96 L. Lenard, Spominek poljske slave, ,Dom in svet”, R. 20, 1907, nr 12, s. 574.

97 Idem, Katarina z Branickih Potocka, „Dom in svet”, R. 20, 1907, nr 12, s. 574.

98 Idem, Pisani časniki na Poljskem, „Dom in svet”, R. 20, 1907, nr 1, s. 42-43.

99 Idem, Kazimierz Przerwa-Tetmajer: „Na skalnem Podhalu”, „Dom in svet”, R. 22, 1909, nr 2, s. 93-94. 
1909, również na łamach „Domu in sveta” Lenard wspominał o dwóch słowiańskich jubileuszach - setnych rocznicach urodzin Juliusza Słowackiego i Mikołaja Gogola. Polacy świętują setną rocznicę urodzin i sześćdziesiątą śmierci poety przez jednych jak pisał - stawianego zaraz po Mickiewiczu, a przez wielu wręcz jako największego poety polskiego. Przyznawał, że jego twórczość jest mało znana Słoweńcom w porównaniu z Mickiewiczem. Podkreślał przy tym, że trzej wieszczowie polscy, Mickiewicz, Słowacki i Krasiński, reprezentanci szkoły romantycznej, są dla Polaków nie tylko największymi poetami polskimi. Twórczość ich bowiem, jako przedstawicieli polskiej emigracji i głosicieli idei mesjanistycznej, posiada również charakter narodowy i polityczny ${ }^{100}$.

Szczególną uwagę poświęcił Lenard kilkudniowej wizycie grupy Słoweńców w Krakowie w dniach 30 kwietnia do 3 maja 1911 roku, przybyłych wraz z Chorwatami w związku z rozpoczęciem działalności Towarzystwa Przyjaciół Jugosławii. Na czele delegacji słoweńskiej stali starosta krajowy Krainy Fran Šuklje, poseł Sejmu Krajowego Krainy Evgen Lampe i ks. dziekan Anton Koblar, a towarzyszyli im reprezentanci różnych słoweńskich towarzystw, wśród nich sam Leopold Lenard, Ivan Kregar, Ivan Štefe, Vojteh Jeločnik, Francè Stelè, Stanislav Masič i Florjan Božič. W składzie komitetu powitalnego witającego gości na dworcu krakowskim byli: prezydent Krakowa Juliusz Leo; prezes Polskiej Akademii Umiejętności, były rektor UJ, a także przywódca stronnictwa konserwatywnego hr. Stanisław Tarnowski; przywódca młodych konserwatystów krakowskich hr. Zdzisław Tarnowski; były rektor UJ Kazimierz Morawski; profesorowie UJ: Marian Zdziechowski, Feliks Koneczny, Ludwik Straszewski, radca dworu Kazimierz Nieć, ks. Franciszek Radziwiłł i Stanisław Jasiński oraz grupa przedstawicieli Izby Panów i byłych posłów Rady Państwa. Lenard opisał na łamach „Domu in sveta” program wizyty, obejmujący zwiedzanie miasta, rauty, wizyty w teatrze, a także wycieczki poza Kraków, między innymi do włości barona Götza w Okocimiu, gdzie miejscowi chłopi witali Słoweńców chlebem i solą ${ }^{101}$. Wspomniał o złożeniu przez Słoweńców wieńców na płycie Rynku krakowskiego, upamiętniającej przysięgę Kościuszki w roku 1794. Specjalnie dla gości słoweńskich wystawiono Wesele Stanisława Wyspiańskiego. Na koniec Lenard zapewnił, że wizyta w Krakowie pozostanie na długo w pamięci Słoweńców i będzie miała dla nich znaczenie w sensie kulturalnym i politycznym.

Pełne ekspresji, przepełnione nutą patriotyczną, jest opowiadanie Lenarda pt. Vrnitev, zamieszczone przed Świętami Wielkanocnymi 1912 roku w „Slovencu”. Opisywał w nim powrót do ojczyzny polskiego sybiraka po ośmiu latach zesłania za agitację polityczną. Anonimowy sybirak, znalazłszy się na polskiej ziemi, jest nieco zagubiony, czytając gazetę, nie rozumie przemian politycznych, jakie się dokonały, ale atmosfera świąt Zmartwychwstania Pańskiego budzi w nim głęboką wiarę w zmartwychwstanie Polski. Kroki swoje kieruje do Krakowa. Oglądając zabytki i pomniki historii, myśli o tym nieustannie. Patrząc na niedokończoną drugą wieżę kościoła Mariackiego, powtarza proroctwo: „Gdy wieża zostanie dokończona -

\footnotetext{
100 Idem, Dva slavenska jubileja, „Dom in svet”, R. 22, 1909, nr 3, s. 234-235.

101 Idem, Slovenci v Krakovu, ,Dom in svet”, R. 24, 1911, nr 6, s. 243-244.
} 
odrodzi się Polska". W Katedrze Wawelskiej słyszy Bogurodzicę, która przypomina mu pełne chwały dzieje Polski i budzi w nim dumę narodową, a także hymn Boże coś Polskę, który przywraca mu wiarę, że „To jeszcze nie koniec Polski” ${ }^{102}$.

Badanie przeszłości Słowian stanowiło dla Lenarda nieodłączny element budowanej przez niego idei wzajemności słowiańskiej. W roku 1912 ukazał się w czasopiśmie „Čas” jego artykuł pt. Kako so nastale slovanske države, w którym opisał również w sposób zwarty początki państwa polskiego ${ }^{103}$. Dwa lata później wyszedł spod jego pióra napisany w Krakowie tekst Kako so propadle slovanske države. Podkreślał fakt, że z wyjątkiem Polski żadne inne państwo słowiańskie nie przetrwało średniowiecza, chociaż i ona rozpadła się na dzielnice i częściowo dostała się pod władzę sąsiednich państw. Na koniec Lenard dochodził do wniosku, że ,[...] przyczyny upadku państw słowiańskich leżały przede wszystkim w nich samych, a zewnętrzne najazdy jedynie ułatwiały rozpad [...]. Dopóki wewnętrzne stosunki nie doprowadziły do rozkładu państwa, żaden obcy wróg nie mógł ich pokonać” ${ }^{104}$.

Już tylko wymienione wyżej przykłady twórczości i działalności publicystyczno-kulturalnej Leopolda Lenarda świadczą niezbicie o tym, że w jego osobie mamy do czynienia ze szczerym polonofilem, orędownikiem ścisłej współpracy Słoweńców i wszystkich Słowian południowych z Polakami.

\section{BIBLIOGRAFIA}

\section{Źródła}

\section{Źródla archiwalne}

Narodna in Univerzitetna Knjižnica (Ljubljana), Rokopisna zbirka (NUK)

Ms. 1880: Zapuščina Leopolda Lenarda

Archiwum Uniwersytetu Jagiellońskiego (AUJ)

S II 188: Katalog główny studentów UJ za rok szkolny 1906/07, filozofia I; studenci zwyczajni.

S II 521: Liber Promotionum Universitatis Iagellonicae 1910-1920.

WF II 344: Katalog studentów i studentek zwyczajnych i nadzwyczajnych, oraz studentów farmacji i rolnictwa zwyczajnych i nadzwyczajnych z roku akademickiego 1906/07 I półrocze.

WF II 504: Teczki akt doktorskich.

WF II 508: Album Doctorum Philosophiae z lat 1888-1927.

\footnotetext{
102 Idem, Vrnitev (Poljska velikonočna slika), „Slovenec”, R. 40, 6 IV 1912.

103 Idem, Kako so nastale slovanske države, „Čas”, R. 6, 1912, nr 3, s. 188-202; nr 4, s. $272-279$.

104 Idem, Kako so propadle slovanske države, „Čas”, R. 8, 1914, nr 4, s. 275-289.
} 


\section{Periodyki}

„Čas” 1909, 1912, 1914.

„Dom in svet” 1907, 1909-1911, 1913, 1917.

„Slovenec” 1909, 1912.

„Świat Słowiański” 1906-1908, 1910, 1912.

„Zora” 1907-1909.

\section{Źródła drukowane}

Molé V., Iz knjige spominov, Ljubljana 1970.

Зубрицький М., Зібрані твори і матеріали у трьох томах, т. 2: Матеріали до біографіі, Львів 2016.

\section{Publikacje Leopolda Lenarda}

Lenard L., Bitka pod Grunvaldom, „Slovenec”, r. 37, 30 X 1909.

Lenard L., Czy Polacy czują się Słowianami. Z prasy słoweńskiej, „Świat Słowiański”, R. 6, t. 2, 1910, nr 69-70, s. 193-195.

Lenard L., Dva slavenska jubileja, „Dom in svet”, R. 22, 1909, nr 3, s. 234-235.

Lenard L., Grunvaldske slavnosti v Krakovu, „Dom in svet”, R. 23, 1910, nr 10, s. 454-458, 499-502.

Lenard L., Henryk Sienkiewicz, „Dom in svet”, R. 30, 1917, nr 1/2, s. 67-69.

Lenard L., Kako so nastale slovanske države, „Čas”, R. 6, 1912, nr 3, s. 188-202; nr 4, s. $272-279$.

Lenard L., Kako so propadle slovanske države, „Čas”, R. 8, 1914, nr 4, s. 275-289.

Lenard L., Kamjenec in Hotin. Potopisna črtica, „Dom in svet”, R. 20, 1907, nr 2, s. 67-71, 111-117, 156-159.

Lenard L., Katarina z Branickih Potocka, „Dom in svet”, R. 20, 1907, nr 12, s. 574.

Lenard L., Kazimierz Przerwa-Tetmajer: „Na skalnem Podhalu”, „Dom in svet”, R. 22, 1909, nr 2, s. 93-94.

Lenard L., Krvav list iz zgodovine ruskega sistema. Prganjanje katoličanov na Ruskem, Ljubljana 1912.

Lenard L., Na slovanski zemlji. Skice z pota, „Dom in svet”, R. 22, 1909, nr 3, s. 125-129.

Lenard L., Naše gorje!, „Zora”, t. 13, 1907, s. 50-54.

Lenard L., Nekaj slovanskih vprašanj. Rusko-poljska sprava, „Čas”, R. 3, 1909, s. 80-86.

[Lenard L.], Der Panslawismus. Eine national-politische Betrachtung, Cilli 1906.

Lenard L., Pisani časniki na Poljskem, „Dom in svet”, R. 20, 1907, nr 1, s. 42-43.

Lenard L., Poljske visoke šole in Slovenci, „Zora”, t. 9-10, 1908-1909, s. 106-108.

Lenard L., Prof. dr. Marvan Zdziechowski: Die Grund-probleme Russlands. Akademischer Verlag, Wien 1907 [recenzja], „Dom in svet”, R. 20, 1907, nr 10, s. 477-478.

Lenard L., Slovenci v Krakovu, „Dom in svet”, R. 24, 1911, nr 6, s. 243-244.

Lenard L., Spominek poljske slave, „Dom in svet”, R. 20, 1907, nr 12, s. 574.

Lenard L., Sveti večer na Ukrajini, „Dom in svet”, R. 22, 1909, nr 1, s. 34-40, 78-83.

Lenard L., V. A. Francjev: Poljskoje slavjanovjedjenije konca XVIII. i pjervoj četvjerti XIX. stol. Praga češkaja. Tipografija „Politika” 1906 [recenzja], „Dom in svet”, R. 20, 1907, nr 12 , s. 566-567. 
Lenard L., Vrnitev (Poljska velikonočna slika), „Slovenec”, R. 40, 6 IV 1912.

Lenard L., Die Wiener ,,Tripel-Allianz und die Lemberger Staats-und Hauptaktion”, Wien 1907.

[Lenard L.], Z cenzury rosyjskiej (własne doświadczenia z niedawnego czasu), „Świat Słowiański”, R. 4, t. 2, 1908, s. 1037-1042.

\section{Opracowania}

Biliński P., Feliks Koneczny (1862-1949). Życie i działalność, Warszawa 2001.

Bobrownicka M., Lud - naród - społeczeństwo. Kategorie zbiorowej tożsamości w odrodzeniu Stowian habsburskich, „Pamiętnik Słowiański”, t. 52, 2002, s. 3-20.

Bobrownicka M., Narkotyk mitu. Szkice o świadomości narodowej i kulturowej Stowian Zachodnich i Potudniowych, Kraków 1995.

Bučar V., Samoizpoved Dr. Leopolda Lenarda, „Meddobje” (Buenos Aires), R. 13, 1973, nr 1.

Cetnarowicz A., Koncepcje federalistyczne wśród Słowian południowych (do roku 1914) [w:] Europa unii i federacji. Idea jedności narodów i państw od średniowiecza do czasów wspótczesnych, red. K. Ślusarek, Kraków 2004, s. 259-272.

Cetnarowicz A., Polacy i Stoweńcy w monarchii habsburskiej. Uwagi na temat wzajemnych stosunków w drugiej połowie XIX wieku, „Prace Historyczne” 1997, nr 121: Austria Polska, 1000 lat sasiedztwa, red. J. Buszko, W. Leitsch, s. 203-220.

Cetnarowicz A., Die polnisch-slowenischen Beziehungen aus der Sicht der slawischen Idee [w:] Entwicklung der Nationalbewegungen in Europa 1850-1914, hrsg. von H. Timmermann, Berlin 1998, s. 207-222.

Cetnarowicz A., Die proösterreichische Einstellungen bei den Polen in der zweiten Hälfte des 19. Jahrhundert [w:] Der Erste Weltkrieg und der Vielvölkerstaat, Wien 2012, s. $11-22$.

Cetnarowicz A., Słoweński ruch narodowy i jego stosunek do spraw polskich (1848-1879), Kraków 1990.

Cetnarowicz A., Słoweńskie programy narodowe do roku 1914, „Prace Komisji Środkowoeuropejskiej PAU”, t. 1, 1993, s. 35-50.

Cetnarowicz A., Stosunki polsko-ukraińskie i polsko-rosyjskie w opinii stoweńskiej w II połowie XIX wieku, ,Acta Historica Neosoliensia, Vedecký časopis pre historicke vedý" 2015, t. 18, s. 161-179.

Corpus studiosorum Universitatis Iagellonicae in seculi XVIII-XX, t. 3: K-L, Kraków 2009.

Darasz Z., Polacy $i$ Słoweńcy we wzajemnych relacjach $w$ świetle publicystyki doby monarchii austro-węgierskiej [w:] W Galicji i nad Sočą. Polacy i Stoweńcy na frontach I wojny światowej, red. A. Cetnarowicz, D. Nećak, S. Pijaj, B. Todorović, Kraków 2014, s. 30-48, 145-152.

Falkovič S., Die polnische Nationalbewegung zwischen Panslavismus, Pangermanismus und Austroslavismus [w:] Osteuropäische Geschichte in vergleichender Sicht, hrsg. M. Müller, Berlin 1996, s. 255-270.

Gantar Godina I., Dr. Leopold Lenard, ,Zgodovinski časopis”, R. 46, 1992, nr 3, s. 395-400.

Gantar Godina I., Neoslavizem in Slovenci, Ljubljana 1994.

Gantar Godina I., Novoslavenska ideja in Slovenci, „Zgodovinski časopis”, R. 43, 1989, nr 4, s. 513-546. 
Gantar Godina I., Slovanska vzajemnost in Slovenci [w:] Zbornik zborovanja slovenskih zgodovinarjev 27 IX 1 X 1994, red. A. Gabrič, Ljubljana 1994, s. 81-86.

Gantar Godina I., Slovene students in Central and Eastern Europe up to 1918, „Dve domovini" 1996, nr 6, s. 249-260.

Giza A., Austroslawizm w XIX wieku, „Przegląd Zachodniopomorski” 1993, z. 1, s. 109-120.

Kleft I., Nekrolog Dr. Leopolda Lenarda, „Delo”, 28 I 1962.

Melik V., Vodopivec P., Slovenski izobraženci in avstrijske visoke šole 1858-1918, „Zgodovinski časopis", t. 40, 1986, s. 269-282.

[Moritsch A.], Austroslavismus. Ein verfrüchtes Konzept zur politischen Neugestaltung Mitteleuropas, Wien-Köln-Weimar 1996.

Moroz-Grzelak L., Bracia Stowianie. Wizje wspólnoty w rzeczywistości, Warszawa 2013.

Oczkow a B., Lénardov „Rozwój historyczny gramatyki słoweńskiej”. Prispevek k zgodovini slovenskega jezikoslovja [w:] Obdobje simbolizma v slovenskem jeziku, književnosti in kulturi, 2. del. Mednarodni simpozij v Ljubljani od 1. do 4. Julija 1982, Ljubljana 1983, s. 295-303.

Pešina J., Słowianie południowi w koncepcji wzajemności słowiańskiej Karela Havlička Borovskiego, „Prace Historyczne” 2010, nr 137, s. 89-96.

Pirjevec A., Slovenski biografski leksikon, Ljubljana 1925-1932.

Rapacka J., Godzina Herdera. O Serbach, Chorwatach i idei jugostowiańskiej, Warszawa 1995.

Rapacka J., Śródziemnomorze - Europa - Bałkany. Studia o literaturach południowosłowiańskich, Kraków 2002.

Rumpler H., Eine Chance für Mitteleuropa. Bürgerliche Emanzypation und Staatsverfall in der Habsburgermonarchie. Österreichische Geschichte 1804-1914, Wien 1997.

Tominšek M., Leopold Lenard (1876-1962), katloliški teolog, filozof, novinar in kulturni delavec, „Bogoslovni vestnik”, t. 62, 2002, nr 4, s. 613-630.

Wereszycki H., Pod bertem Habsburgów. Zagadnienia narodowościowe, Kraków 2015. 